U.S. Department of the Interior

U.S. Geological Survey

\title{
Proposal and Work Plan to Calibrate and Verify a Water-Quality Model to Simulate Effects of Wastewater Discharges to the Red River of the North at Drought Streamflow near Fargo, North Dakota, and Moorhead, Minnesota
}

By Edwin A. Wesolowski

Open-File Report 00-190

In cooperation with the Minnesota Pollution Control Agency 


\title{
U.S. DEPARTMENT OF THE INTERIOR \\ BRUCE BABBITT, Secretary
}

\author{
U.S. GEOLOGICAL SURVEY \\ CHARLES G. GROAT, Director
}

Any use of trade, product, or firm names is for descriptive purposes only and does not imply endorsement by the U.S. Government.

For additional information write to:

\section{District Chief}

U.S. Geological Survey

Water Resources Division

821 East Interstate Avenue

Bismarck, ND 58501-1199

Copies of this report can be purchased from:

U.S. Geological Survey

Information Services

Box 25286

Denver, CO 80225-0286 


\section{CONTENTS}

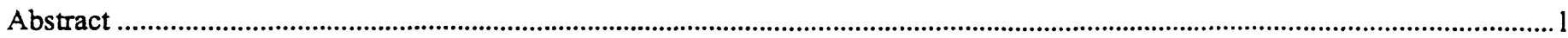



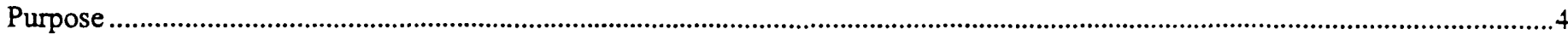

Proposal to calibrate and verify a dynamic water-quality model .................................................................................................

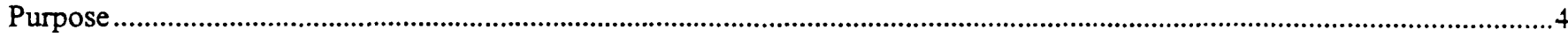

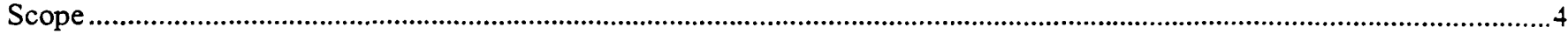

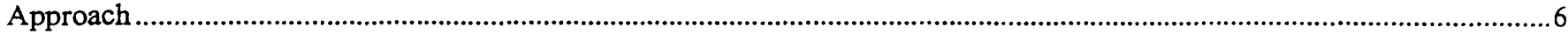

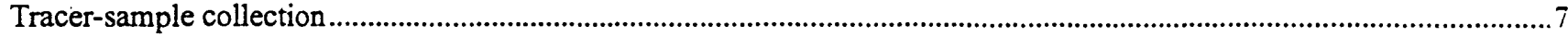



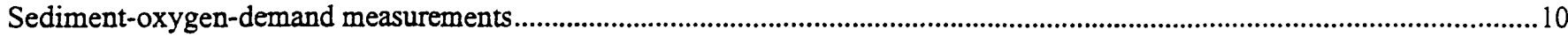

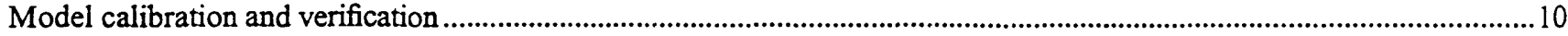

Work plan to calibrate and verify a water-quality model .................................................................................................................10

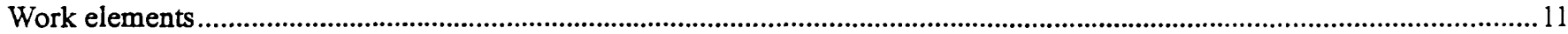

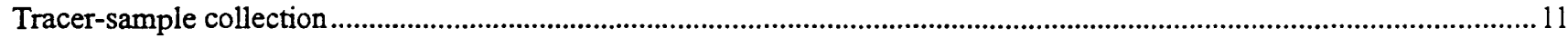

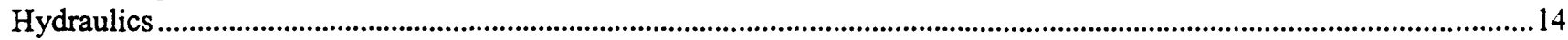

Sediment-oxygen-demand measurements ..........................................................................................................................15

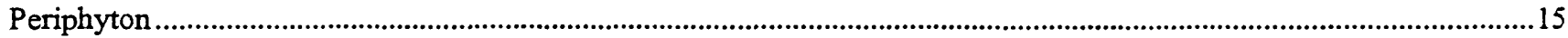

Synoptic water-quality sample collection ..............................................................................................................................16

Work plan to monitor drought formation …………........................................................................................................................

Review of selected historical drought indices.............................................................................................................................

Drought indices annual review and report .........................................................................................................................32

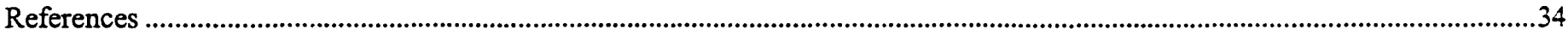

Supplements:

1. Spreadsheet for calculation of traveltimes for dye sampling at 60 cubic feet per second headwater streamflow.............................35

2. Tracer-sampling instructions .....................................................................................................................................................37

3. Supplies and equipment needed by the tracer-injection crew....................................................................................................39

4. Supplies and equipment needed by the tracer sampling crew.......................................................................................................40

5. Spreadsheet for dye sampling schedule for Red River of the North at 60 to 100 cubic feet per second ( 60 cubic feet per second headwater plus effluent and Sheyenne River).....................................................................................41

6. Spreadsheet for dye-sampling schedule flowsheet, 60 to 100 cubic feet per second.......................................................................

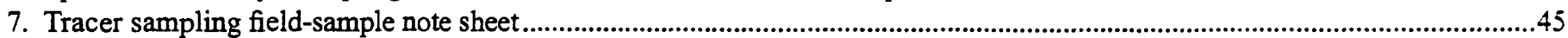

8. Sediment-oxygen-demand measurement sheet ........................................................................................................................46

9. Respirometer dissolved-oxygen note sheet for use with Yellow Springs dissolved-oxygen recorder..............................................47

10. Supplies and equipment needed for sediment-oxygen-demand measurements ..............................................................................48

11. Spreadsheet for synoptic water-quality sampling schedule flowsheet, 60 to 100 cubic feet per second--

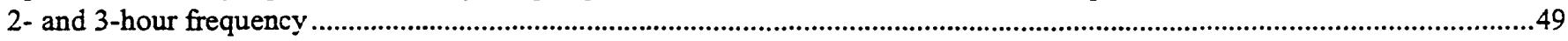

12. Multiparameter water-quality instrument (Hydrolab or similar) calibration sheet...................................................................54

13. Supplies and equipment needed by each of four synoptic-sampling crews..............................................................................5.

14. Home page for the U.S. Drought Monitor ………………………...........................................................................................56

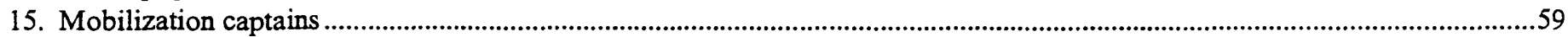

16. 9-month time line of project "GO" actions prior to actual project start up................................................................................60

\section{FIGURES}

1. Location of study reach on the Red River of the North and data-collection sites from Fargo, North Dakota, to Georgetown, Minnesota.

2. Location of data-collection sites on the Red River of the North from Fargo, North Dakota, and Moorhead, Minnesota, to Georgetown, Minnesota.

3. Hydrograph of mean daily streamflow for the Red River of the North at Fargo, North Dakota, gaging station (05054000), 1960-61

4. Hydrograph of mean daily streamflow for the Red River of the North at Fargo, North Dakota, gaging station (05054000), 1963-64

5. Hydrograph of mean daily streamflow for the Red River of the North at Fargo, North Dakota, gaging station (05054000), 1975-76 
FIGURES, Continued

6. Hydrograph of mean daily streamflow for the Red River of the North at Fargo, North Dakota, gaging station (05054000), 1976-77

7. Hydrograph of mean daily streamflow for the Red River of the North at Fargo, North Dakota, gaging station (05054000), 1980-81

8. Hydrograph of mean daily streamflow for the Red River of the North at Fargo, North Dakota, gaging station (05054000), 1986-87

9. Hydrograph of mean daily streamflow for the Red River of the North at Fargo, North Dakota, gaging station (05054000), 1988-89

10. Hydrographs of mean daily streamflow for the Otter Tail River below Orwell Dam near Fergus Falls, Minnesota (05046000), and Red River of the North at Fargo, North Dakota (05054000), gaging stations, July through September 1960 and 1961

11. Hydrographs of mean daily streamflow for the Otter Tail River below Orwell Dam near Fergus Falls, Minnesota (05046000), and Red River of the North at Fargo, North Dakota (05054000), gaging stations, July through September 1963 and 1964.

12. Hydrographs of mean daily streamflow for the Otter Tail River below Orwell Dam near Fergus Falls, Minnesota (05046000), and Red River of the North at Fargo, North Dakota (05054000), gaging stations, July through September 1976 and 1977.

13. Hydrographs of mean daily streamflow for the Otter Tail River below Orwell Dam near Fergus Falls, Minnesota (05046000), and Red River of the North at Fargo, North Dakota (05054000), gaging stations, July through September 1981 and 1987.

14. Hydrographs of mean daily streamflow for the Otter Tail River below Orwell Dam near Fergus Falls, Minnesota (05046000), and Red River of the North at Fargo, North Dakota (05054000), gaging stations, July through September 1988 and 1989.

15. Graphs showing Palmer Hydrological Drought Index, monthly averages for North Dakota climatic division 06, 1895-1999.

16. Graphs showing Palmer Hydrological Drought Index, monthly averages for Minnesota climatic division 04, 1895-1999.

\section{TABLES}

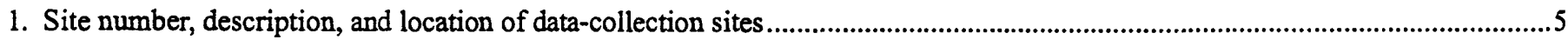

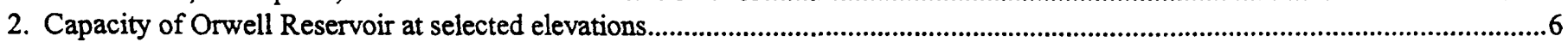

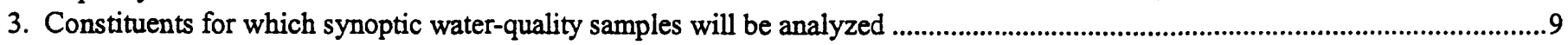




\author{
ByEdwin A. Wesolowski
}

\begin{abstract}
This report presents a proposal for conducting a water-quality modeling study at drought streamflow, a detailed comprehensive plan for collecting the data, and an annual drought-formation monitoring plan. A 30.8 mile reach of the Red River of the North receives treated wastewater from plants at Fargo, North Dakota, and Moorhead, Minnesota, and streamflow from the Sheyenne River. The water-quality modeling study will evaluate the effects of continuous treated-wastewater discharges to the study reach at drought streamflow. The study will define hydraulic characteristics and reaeration and selected reaction coefficients and will calibrate and verify a model.
\end{abstract}

The study includes collecting synoptic water-quality samples for various types of analyses at a number of sites in the study reach. Dye and gas samples will be collected for traveltime and reaeration measurements. Using the Lagrangian reference frame, synoptic water-quality samples will be collected for analysis of nutrients, chlorophyll a, alkalinity, and carbonaceous biochemical oxygen demand. Field measurements will be made of specific conductance, $\mathrm{pH}$, air and water temperature, dissolved oxygen, and sediment oxygen demand. Two sets of water-quality data will be collected. One data set will be used to calibrate the model, and the other data set will be used to verify the model.

The DAFLOW/BLTM models will be used to evaluate the effects of the treated wastewater on the water quality of the river. The model will simulate specific conductance, temperature, dissolved oxygen, carbonaceous biochemical oxygen demand, total nitrogen (organic, ammonia, nitrite, nitrate), total orthophosphorus, total phosphorus, and phytoplankton as chlorophyll a.

The work plan identifies and discusses the work elements needed for accomplishing the data collection for the study. The work elements specify who will provide personnel, vehicles, instruments, and supplies needed during data collection. The work plan contains instructions for data collection; inventory lists of needed personnel, vehicles, instruments, and supplies; and examples of computations for determining quantities of tracer to be injected into the stream. The work plan also contains an annual drought-formation monitoring plan that includes a 9-month time line that specifies when essential planning actions must occur before actual project start up.

Drought streamflows are rare. The annual drought-formation monitoring plan is presented to assist project planning by providing early warning that conditions are favorable to produce drought streamflow. The plan to monitor drought-forming conditions discusses the drought indices to be monitored. To establish a baseline, historic values for some of the drought indices for selected years were reviewed. An annual review of the drought indices is recommended. 


\section{INTRODUCTION}

The Clean Water Act requires all states to develop and implement "total maximum daily loads" (TMDL) for surface water where existing controls are not adequate to achieve instream water-quality standards. A TMDL is a tool for implementing State water-quality standards and is based on the relation between pollution sources and instream water-quality conditions (U.S. Environmental Protection Agency, 1991). State and Federal agencies have determined that a TMDL should be developed for a reach of the Red River of the North (hereinafter referred to as the Red River).

During June 1994, a TMDL work group, which consists of Federal, State, and local agency representatives, was organized to begin developing a TMDL for a reach of the Red River near Fargo, N. Dak., and Moorhead, Minn. Two events prompted action: (1) Fargo's wastewater-treatment plant was enlarged and upgraded; and (2) in order to reduce effluent ammonia concentrations, stricter controls were recommended for Moorhead's wastewater-treatment plant. Fargo's upgraded plant removes ammonia and allows continuous discharge to the Red River. Moorhead's plant, which already continuously discharges to the Red River, does not remove ammonia by advanced treatment.

An implemented TMDL results in an allocation of loads for all sources for a range of streamflows in order to establish a proper balance of controls between point and nonpoint sources. At this juncture, all of the loading sources are not known. To meet the immediate needs of the two municipal treatment plants, the work group decided that the TMDL would be developed in phases. Initially, the work group focused on drought streamflow and on water-quality issues limited to ammonia and dissolved-oxygen concentrations. Further development of the TMDL would proceed on the basis of need and as information became available. At drought streamflow, loads to the Red River can exceed the river's capability to assimilate waste and can reduce the dissolved oxygen to undesirable concentrations. Treated wastewater dominates loading sources at drought streamflow in the reach of the Red River near Fargo and Moorhead.

The TMDL work group defined drought streamflow as the 7-day, 10-year, low flow (7Q10) for specified months of the year. The 7Q10 streamflow represents the minimum 7-consecutive-day average streamflow expected to be exceeded in all but 1 year in 10. The specific 7Q10 that will be used in the water-quality modeling study discussed in the proposal of this report will be quantified in a later section.

A previous study (Wesolowski, 1994) reported traveltime, water-quality conditions, and reaction coefficients at median streamflow, 150 to 250 cubic feet per second $\left(\mathrm{ft}^{3} / \mathrm{s}\right.$ ), for a 30.8-mile (mi) reach of the Red River near Fargo and Moorhead. In that study, the Enhanced Stream Water Quality Model (QUAL2E) was calibrated and verified. The results of that study have provided some tools, including predictive capability, and information to help develop the TMDL for the Red River.

The model from Wesolowski (1994) was used in a subsequent report (Wesolowski, 1996a) to simulate wastewater effects of several hypothetical input water-quality conditions on the same reach of the Red River when the headwater streamflow was $16 \mathrm{ft}^{3} / \mathrm{s}$. This streamflow represents the 7Q10 during 1953-88 (June through September) for the Red River of the North at Fargo, N. Dak., gaging station (05054000). Seasonal variation of streamflow was considered by the TMDL work group and they determined that June through September was the season most critical to water quality. The work group also decided that for the entire period of record (1902-88), the most representative period for the simulation was 1953-88. The streamflow data set for 1953-88 represents streamflows after regulation by Orwell Dam (fig. 1).

The results of Wesolowski's (1996a) study were not satisfactory to all members of the TMDL work group because the range of effects on the water quality of the Red River was not specific enough for some uses as required by the TMDL work group. Although unknown, it is expected that pools and riffles will form in the Red River channel as streamflow decreases from median to drought streamflow. Pool-and-riffle formations will cause changes in channel hydraulics that can affect traveltime, water-quality conditions, and reaction coefficients. The reaeration coefficients at median streamflow from Wesolowski (1994) may be unrepresentative at 7Q10 streamflow because of the change in channel hydraulics from median to drought streamflow. The uncertainty of applying a reaeration coefficient determined at median streamflow to a 7Q10 streamflow Wesolowski (1996b), coupled with the inherent uncertainty in measuring reaeration, resulted in using low-, middle-, and high-value reaeration coefficients to simulate effects of each set of hypothetical input conditions Wesolowski (1996a). This approach produced, therefore, a range of simulated wastewater effects on the water quality of the river on the basis of one set of hypothetical input conditions and three reaeration coefficients as variables. 


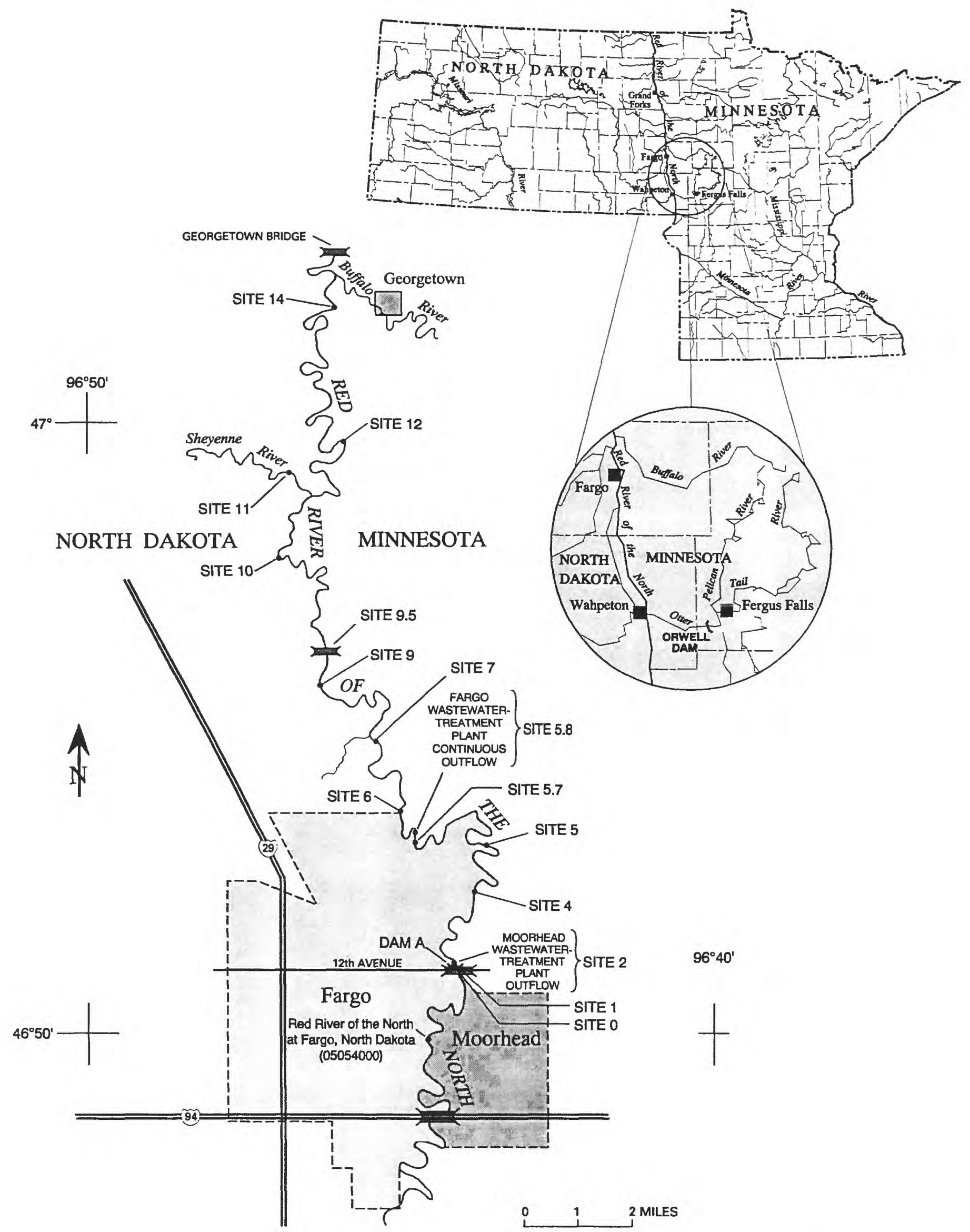

Figure 1. Location of study reach on the Red River of the North and data-collection sites from Fargo, North Dakota, to Georgetown, Minnesota. 
Because the effects that were simulated by a model that was calibrated and verified at median streamflows were not satisfactory at drought streamflow, the TMDL work group decided that a water-quality model that is calibrated and verified with data collected at drought streamflows is needed. A tracer and water-quality study at drought streamflow will add information about hydraulics and reaction coefficients to the North Dakota hydrology data base. In particular, a study of the Red River at drought streamflow will add information about reaeration of one of North Dakota's flat-sloped prairie rivers. Water-resource managers also could use this information to set proper effluent limits so that beneficial uses of the river will be protected.

Streamflows of 7Q10 magnitude are rare and require a combination of climatic events in order to occur. These events usually are associated with a drought. The U.S. Geological Survey has a vital interest in collecting data during extreme hydrologic events. However, planning and executing this type of study is difficult because it is not known when the combination of climatic events that produce low-magnitude streamflow will occur. When it becomes evident that streamflows have decreased to low levels, there is not enough time to plan and perform the data-collection phase of the study. Therefore, a detailed work plan is needed to help plan and prepare as much as possible beforehand.

\section{PURPOSE}

The purpose of this report is to present a proposal for conducting a water-quality modeling study at drought streamflow, a detailed comprehensive plan for collecting the data, and an annual drought-formation monitoring plan. Considerable time may pass from the time the proposal is prepared to the time when the study is implemented. Therefore, the proposal for conducting the study and the plan for accomplishing the data collection are incorporated into one document so that the necessary information will be readily available when streamflow conditions meet the criteria for implementation of the study.

\section{PROPOSAL TO CALIBRATE AND VERIFY A DYNAMIC WATER-QUALITY MODEL}

\section{Purpose}

The purpose of the water-quality modeling study is to evaluate the effects of continuous treated-wastewater discharges on the water quality of a 30.8-mi reach of the Red River. The reach is near Fargo and Moorhead. Data collection will take place during drought streamflow under summer conditions. Specific objectives of the study are to (1) define hydraulic characteristics, including traveltime and longitudinal dispersion; (2) define reaeration and selected reaction coefficients; and (3) calibrate and verify a model that can simulate water-quality conditions at drought streamflow.

\section{Scope}

The study reach begins just downstream of Dam A, locally referred to as North Dam (B. Montgomery, U.S. Army Corps of Engineers, oral commun., 1990). Dam A is located about 0.1 mi downstream of the 12th Avenue North bridge in Fargo. The study reach extends $30.8 \mathrm{mi}$ downstream from Dam A to a site $0.8 \mathrm{mi}$ upstream of the confluence of the Buffalo and Red Rivers (fig. 1). Samples will be collected at one headwater-source site, three point-source sites, eight comparative sites, one dye and gas site, and possibly one auxiliary headwater-source site. Synoptic water-quality samples will be collected at 12 (possibly 13) of the sites, dye samples will be collected at 9 of the sites, gas samples will be collected at 7 of the sites, and sediment oxygen demand will be measured at 10 of the sites (table 1).

Data need to be collected at headwater (site 1) streamflows between about 20 and $100 \pm 10 \mathrm{ft}^{3} / \mathrm{s}$. Tributary streamflow and municipal effluent discharges will add an average of about $25 \mathrm{ft}^{3} / \mathrm{s}$ to the headwater streamflow in the study reach. For illustrative purposes in this report, the data collection was based on three headwater streamflow scenarios of 30,60 , and $90 \mathrm{ft}^{3} / \mathrm{s}$. The rationale for these scenarios is related somewhat to the discharge magnitude from Orwell Reservoir during drought conditions and to project needs. 


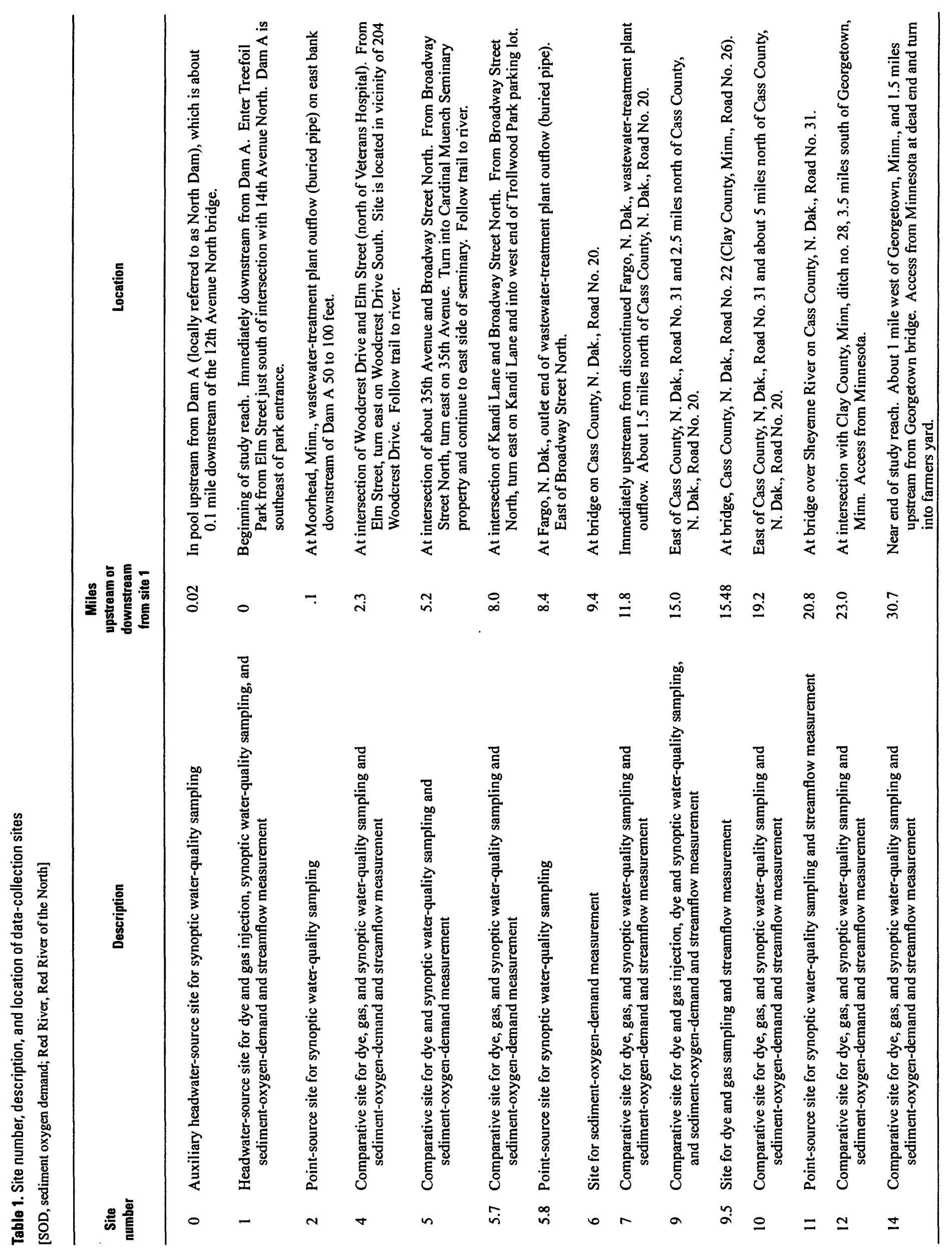




\section{Approach}

Since 1988, streamflows in the Red River Basin generally have been greater than normal. Thus, using a larger data set than the 1953-88 (June through September) data set that was used in Wesolowski (1996a) for the Red River of the North at Fargo, N. Dak., gaging station (05054000) will increase the 7Q10. Using a 1942-94 (June through August) data set, Wiche and Williams-Sether (1997) estimated the $7 \mathrm{Q} 10$ to be $38.3 \mathrm{ft}^{3} / \mathrm{s}$ for the summer period for that station. Historically, streamflows in the basin are lower in September than in August. Adding the month of September to the 1942-94 data set lowers the $7 \mathrm{Q} 10$ from 38.3 to $25 \mathrm{ft}^{3} / \mathrm{s}$. For the remainder of this proposal, $25 \mathrm{ft}^{3} / \mathrm{s}$ will be used for the $7 \mathrm{Q} 10$ for June through September 1942-94. In Wiche and Williams-Sether (1997), the data during 1942-94 were used because that data represent streamflows after regulation of Lake Traverse and Big Slough at White Rock Dam in 1941.

Regulated releases of water stored in Orwell Reservoir near Fergus Falls, Minn., defer attainment of the 7Q10 in the Red River near Fargo and Moorhead. During drought conditions, the reservoir-operating procedure specifies an $80-\mathrm{ft}^{3} / \mathrm{s}$ water release during the first 30 days when reservoir elevations are between 1,060 and 1,064 feet ( $\mathrm{ft}$ ) above sea level. After 30 days, the water release equals inflow plus $10 \mathrm{ft}^{3} / \mathrm{s}$ or $50 \mathrm{ft}^{3} / \mathrm{s}$, whichever is greater. The water release equals inflow when the reservoir elevations are between 1,048 and 1,060 $\mathrm{ft}$ above sea level. During drought-operation conditions, coordination with the Minnesota Department of Natural Resources is maintained because streamflow magnitude and variation affect instream fishery (oral commun., Gordon Heitzmann, U.S. Army Corps of Engineers, 1990). Orwell Reservoir capacity is 14,100 acre-feet (acre- $\mathrm{ft}$ ) at an elevation of $1,070 \mathrm{ft}$ above sea level. Of the 14,100 acre-ft, 13,400 acre- $\mathrm{ft}$ is controlled storage above an elevation of $1,048 \mathrm{ft}$ above sea level. The minimum operating elevation of the reservoir is $1,048 \mathrm{ft}$ (table 2). After the 30 days of $80-\mathrm{ft}^{3} / \mathrm{s}$ water release, disregarding further inflow, about 48 days would be required to release the remaining controlled storage at $50 \mathrm{ft}^{3} / \mathrm{s}$.

Table 2. Capacity of Orwell Reservoir at selected elevations

\begin{tabular}{cc}
\hline $\begin{array}{c}\text { Elevation } \\
\text { (feet above sea level) }\end{array}$ & $\begin{array}{c}\text { Capacity } \\
\text { (acre-feet)' }\end{array}$ \\
\hline 1,080 & 28,300 \\
1,070 & 14,100 \\
1,064 & 8,300 \\
1,060 & 5,500 \\
1,048 & 700 \\
1,040 & 4 \\
\hline
\end{tabular}

\footnotetext{
${ }^{1}$ Estimated from storage capacity curve, 1985 survey, U.S. Army Corps of Engineers. Dead storage is 150 acre-feet.
}

Data collection must take place during July and/or August when maximum water temperatures and minimum dissolved-oxygen concentrations normally occur. Water releases from Orwell Reservoir probably will defer the 7Q10 during July through August during 1-year droughts. Consequently, the 7Q10 likely will be attained only in a prolonged multiyear drought when drought conditions are widespread throughout basins in North Dakota and Minnesota.

To accomplish the objectives of this study, the headwater streamflow as measured at site 1 should approach the drought streamflow of $25 \mathrm{ft}^{3} / \mathrm{s}$. As the streamflow recession occurs, data collection will be initiated as streamflow approaches one of several streamflow scenarios. During the streamflow recession, if streamflows are getting close to one of the streamflow scenarios and natural recession does not produce the required streamflow, releases from Orwell Dam possibly could be regulated in order to accomplish the required streamflow.

During the study, communication will be established with the U.S. Army Corps of Engineers, St. Paul, Minn., and the Minnesota Department of Natural Resources. Communication with the U.S. Army Corps of Engineers is important because the Corps controls water releases from Orwell Dam. Therefore, the Corps could help eliminate unexpected, abrupt 
streamflow changes that could affect the accuracy of the collected data. Communication with the Minnesota Department of Natural Resources is important because the Department has interest in fish habitat in the Otter Tail River, and fish habitat is affected by streamflow magnitude and variation. Therefore, the Department will be kept informed of the study planning and execution.

\section{Tracer-Sample Collection}

Tracer-sample collection will include traveltime, longitudinal dispersion, and reaeration measurements. The tracer used for traveltime measurements is rhodamine WT dye, and the tracer used for reaeration measurements is propane gas (commercial grade). The dye and gas injections will be done simultaneously. During the 1989-90 study (Wesolowski, 1994), reaeration measurements were made when streamflows were about $200 \mathrm{ft}^{3} / \mathrm{s}$ and about $450 \mathrm{ft}^{3} / \mathrm{s}$. During that study, most (about 54 to 61 percent) of the variance in simulated dissolved-oxygen concentration was attributed to the reaeration coefficient (Wesolowski, 1996b). Quantification of reaeration is needed for headwater streamflows between 20 and $100 \pm 10 \mathrm{ft}^{3} / \mathrm{s}$. Some reaeration equations indicate that reaeration varies directly with velocity and slope and inversely with depth. Consequently, in some waste-assimilation studies where reaeration was not measured, reaeration was assumed to increase when depths decreased. However, Smoot (1987) has shown that reaeration decreased with depth when pools and riffles formed in the river channel. Pools and riffles are suspected to exist in the river channel at the study reach during the 7Q10. Because the streamflow magnitudes for pool-and-riffle formation in the study reach are not known, tracer samples will be collected when headwater streamflow is between 10 and $30 \mathrm{ft}^{3} / \mathrm{s}$, between about 50 and $70 \mathrm{ft}^{3} / \mathrm{s}$, and between about 90 and $110 \mathrm{ft}^{3} / \mathrm{s}$. Methods described in Kilpatrick and Wilson (1989) will be used to measure traveltime. The modified-tracer technique developed by Kilpatrick and others (1989) will be used to measure reaeration.

The dye will be slug injected into the stream. Two injections will be made in the study reach. The first injection will be made at site 9 in the downstream part of the study reach, and the dye samples will be collected at sites $9.5,10,12$, and 14 (fig. 1). The second injection will be made at site 1 in the upstream part of the study reach, and the dye samples will be collected at sites $4,5,5.7,7,9.5$, and 10 . During the passage of the dye cloud, dye samples will be collected manually at various time intervals until the dye concentrations decrease to either 2 percent of the peak or 0.1 microgram per liter $(\mu \mathrm{g} / \mathrm{L})$, whichever is larger at each site. Automatic dye samplers may be used to measure the "tail" of the recession curve. Two dye samples will be collected during each time interval. One dye sample will be analyzed immediately in the field using a field-calibrated fluorometer, and the other sample will be analyzed later in the U.S. Geological Survey Laboratory in Bismarck, N. Dak., using a laboratory-calibrated fluorometer. One laboratory-calibrated fluorometer will be used to analyze all of the samples in the laboratory. The dye-sampling crew will make channel cross-section measurements between injections.

Propane gas will be injected into the stream through small-pore diffusers. The gas is not readily absorbed into water, and only 20 to 50 percent of the amount that is injected actually will be absorbed. Absorption efficiency is related to the water depth, and about $2 \mathrm{ft}$ of depth is required for efficient absorption. The propane gas will be injected at a constant rate until it arrives at the last downstream sampling site. Because continuous injection is used, longitudinal dispersion is no longer a factor in decreased concentration; therefore, the concentration will decrease only by desorption and dilution. Consequently, by using constant-rate gas injection, tracer loss is not considered in the calculations.

Extrapolation of a relation between streamflow and traveltime (Wesolowski, 1994) estimates that the traveltime and velocity through the study reach are about 100 hours and 0.45 feet per second ( $\mathrm{ft} / \mathrm{s})$, respectively, when the streamflow is $60 \mathrm{ft}^{3} / \mathrm{s}$ and about 130 hours and $0.34 \mathrm{ft} / \mathrm{s}$, respectively, when the streamflow is $30 \mathrm{ft}^{3} / \mathrm{s}$. The traveltime needs to be considered in order to have a measurable gas concentration at the site furthest downstream. If the traveltime is too long, all gas could be desorbed before it reaches the last sampling site. Based on these estimates, injections are planned at two locations in the study reach. A third injection is a contingency if traveltimes are longer than estimated and desorption prematurely depletes the amount of gas in the water. In the case of two injections, the study area will be divided approximately in half. The first injection will be made at site 9 in the downstream part of the study reach. Gas samples will be collected after the gas concentration in the reach rises to a plateau. Gas-plateau concentrations are defined by the dye-response curve (Kilpatrick and others, 1989, p. 26). The gas plateau is reached when the dye concentration reaches background conditions. In this study, background concentrations are defined as 2 percent of the peak dye concentration or $0.1 \mu \mathrm{g} / \mathrm{L}$, whichever is larger. Seven duplicate gas samples will be collected manually in 3 hours at 30-minute intervals. In order to meet residence requirements, gas samples will be collected only at sites $9.5,12$, and 14 (fig. 1). The second 
injection will be made at site 1 in the upstream part of the study reach. In order to meet residence requirements, gas samples will be collected only at sites 4, 5.7, 7, and 10. Gas samples will be shipped unchilled in a cooler by air to the U.S. Geological Survey Central Laboratory in Ocala, Fla. Samples also will be collected and analyzed for methylene blue active substance (MBAS) to determine if surfactants are interfering with reaeration. When streamflow is $60 \mathrm{ft}^{3} / \mathrm{s}$, the tracer sampling will take about 51 hours ( 2.1 days) for the upstream reach and 62 hours ( 2.6 days) for the downstream reach. It will take about 1 day to relocate and set up equipment between injections.

A total of 15 people will be needed to conduct the tracer sampling. Before tracer-sample collection, one 2-person crew will make streamflow measurements at all dye-sampling sites in order to determine the location of the 50-percent streamflow line where tracer samples will be collected. Streamflow measurements also will be made coincident with the arrival of the dye peak at gas-sampling sites. Depending upon the arrival of the dye peak at the sampling site, streamflow measurements may have to be made at night. During two 12-hour shifts, four 2-person crews will collect samples, and one 1 -person crew will perform the tracer injections. In addition, two people--one from the U.S. Geological Survey and one from the cooperating agency--will be required as backups. Personnel requirements include a project leader. The 15 people will consist of 8 U.S. Geological Survey personnel and 7 cooperating agency personnel.

\section{Synoptic Water-Quality Sample Collection}

The results of the uncertainty report (Wesolowski, 1996b) indicate that some headwater- and point-source constituents are large components of the variance when simulating that constituent. In order to reduce this variance and more accurately define diurnal variation in concentration, a greater frequency of sampling is proposed for this study for the headwater- and point-source water-quality sites than for the 1989-90 study (Wesolowski, 1994). Samples will be collected during a 24-hour period in 2-hour intervals at some sites and in 3-hour intervals at other sites. Whole-water samples will be collected from multiple verticals in the cross section using a sediment-sampling technique to assure a representative sample (Shelton, 1994). Synoptic water-quality samples will be collected during two separate sampling periods in order to calibrate and verify the water-quality model. One data set will be used to calibrate the model, and the other data set will be used to verify the model. Sample collection will be based on a Lagrangian reference frame in which the same parcel of water is sampled at each site. This method of sampling results in a more accurate definition of the changes in water quality because the same volume of water is sampled at each site. Calculated decay rates, therefore, should be more representative of actual decay rates. The second data set will be collected as soon as practical after the first data set. However, existing climatic and streamflow conditions will dictate actual sampling time for the second data set. Ideally, the verification data set should be collected under hydrologic conditions different from those that created the water-quality equilibrium in the water column when the calibration data set was collected. For example, the verification data set could be collected in the year following collection of the calibration data set, provided, of course, drought-streamflow conditions exist.

Synoptic water-quality sampling will be undertaken after tracer sampling is completed. For the Lagrangian reference-frame sampling, a volume of water is tagged with dye. Sampling begins at the next downstream site after the dye peak passes. Synoptic water-quality samples will be collected at 12 sites. These 12 sites include 1 headwater-source site (site 1); 3 point-source sites (sites 2, 5.8, and 11); and 8 comparative sites (sites 4, 5, 5.7, 7, 9, 10, 12, and 14) (fig. 1; table 1). A thirteenth site (site 0 ), which is located in the pool upstream from Dam A, also may be needed. The need for a site upstream from Dam A will be determined, in part, by whether or not a representative sample of the headwater conditions can be collected at site 1 . Samples will be collected during a 24-hour period in 2-hour intervals at sites 1,2 , and 5.8 and in 3-hour intervals at sites $4,5,5.7,7,9,10,11,12$, and 14. A total of 39 water-quality samples will be collected at headwater-source site 1 and point-source sites 2 and 5.8 using 2-hour intervals, and a total of 81 samples will be collected at comparative sites $4,5,5.7,7,9,10,12$, and 14 and point-source site 11 using 3-hour intervals. Using the 2-and 3-hour interval sampling schedule, a total of 120 samples will be collected. If this sampling schedule cannot be achieved by the sampling crew because sampling is too frequent to allow sufficient sampling-process time, the sampling frequency will be reduced to 3- and 4-hour intervals, respectively, for a total of 90 samples. Samples that may be collected at site 0 are not included in the sample totals. The samples will be analyzed for the constituents listed in table 3 . 
Table 3. Constituents for which synoptic water-quality samples will be analyzed

\begin{tabular}{|c|c|}
\hline Field-analyzed constituent & Laboratory-analyzed constituent \\
\hline Specific conductance & Turbidity \\
\hline $\mathrm{pH}$ & 5- or 20-day carbonaceous biochemical oxygen demand ${ }^{1}$ \\
\hline Air temperature & Total nitrite as nitrogen \\
\hline Water temperature & Total nitrate plus nitrite as nitrogen \\
\hline Barometric pressure & Total ammonia as nitrogen \\
\hline \multirow[t]{3}{*}{ Dissolved oxygen } & Total ammonia plus organic nitrogen as nitrogen \\
\hline & Total phosphorus as phosphorus \\
\hline & Total orthophosphorus as phosphorus \\
\hline \multirow[t]{4}{*}{ Sediment oxygen demand ${ }^{2}$} & Methylene blue active substance (MBAS) ${ }^{3}$ \\
\hline & Phytoplankton as chlorophyll a \\
\hline & Phytoplankton biomass (dry and ash weight) \\
\hline & Periphyton chlorophyll $a^{4}$ \\
\hline Alkalinity ${ }^{5}$ & Periphyton biomass (dry and ash weight) ${ }^{4}$ \\
\hline \multicolumn{2}{|c|}{$\begin{array}{l}{ }^{1} \text { Incubation time will be determined when arrangements are made with the North Dakota Department } \\
\text { f Health to process the samples. }\end{array}$} \\
\hline \multicolumn{2}{|c|}{$\begin{array}{l}{ }^{2} \text { These samples will be collected at a different time and not in conjunction with the synoptic } \\
\text { ter-quality sampling. }\end{array}$} \\
\hline \multicolumn{2}{|c|}{$\begin{array}{l}{ }^{3} \text { These samples will be collected at selected sites during gas and synoptic water-quality sampling to } \\
\text { etermine if MBAS is interfering with reaeration. }\end{array}$} \\
\hline \multicolumn{2}{|c|}{$\begin{array}{l}\text { The need for sample collection will be determined at the time of sampling and will depend upon } \\
\text { whether the amount of periphyton growing in the channel is sufficient to affect the oxygen budget. Funds } \\
\text { to collect these data are not included in the budget. }\end{array}$} \\
\hline
\end{tabular}

If streamflow is $60 \mathrm{ft}^{3} / \mathrm{s}$, the traveltime will be about 100 hours (4.2 days). When the 24-hour sampling time at the last site is added to the 100 hours, the synoptic water-quality sampling at $60 \mathrm{ft}^{3} / \mathrm{s}$ will take 5.2 days. A total of 27 people will be needed to conduct the synoptic water-quality sampling. During two 12-hour shifts, eight 2-person teams will collect samples; two 1-person teams will make discharge measurements; two 2-person teams will make dye-concentration measurements; one 2-person team will determine alkalinities; and 2 people--1 from the U.S. Geological Survey and 1 from the cooperating agency--will be required as backups. In addition, personnel requirements will include a project leader. The 27 people will consist of 14 U.S. Geological Survey personnel and 13 cooperating agency personnel. The synoptic water-quality sampling teams and the discharge- and dye-measuring teams will not be needed the entire sampling time. Therefore, when available, those teams will make channel cross-section measurements.

Algae are expected to affect the oxygen budget more at lower streamflows than at the streamflows during the 1989-90 study (Wesolowski, 1994). Samples were not analyzed for periphyton in the 1989-90 study because periphyton were not considered significant to the oxygen budget at those streamflows. However, at shallower depths during drought streamflow, it is possible that periphyton will be more abundant and will have a greater effect on dissolved oxygen. Periphyton analyses have not been planned, but, before synoptic water-quality sampling begins, it will be necessary to determine if periphyton are important to the oxygen budget and if samples should be collected and analyzed. Additional planning will be needed if periphyton samples are collected.

The proposed budget will not include a cost estimate for water-quality sample analysis, except for propane and phytoplankton samples. The assumption is made that the water-quality samples will be analyzed by the North Dakota Department of Health Laboratory. The U.S. Geological Survey Laboratory in Ocala, Fla., will analyze the propane and phytoplankton samples. 


\section{Sediment-Oxygen-Demand Measurements}

Sediment oxygen demand is a significant dissolved-oxygen sink (Wesolowski, 1994) and is responsible for 10 to 15 percent of the variance in simulated dissolved-oxygen concentrations (Wesolowski, 1996a). Sediment oxygen demand will be measured with the objective of reducing the variance by measuring at more sites than were measured during the 1989-90 study (Wesolowski, 1994). Therefore, sediment oxygen demand will be measured at 10 sites (table 1). The techniques used are described in Murphy and Hicks (1986).

\section{Model Calibration and Verification}

Because of variable discharges from the wastewater-treatment plants in Fargo and Moorhead, the streamflows and water quality downstream from the plants will vary at low headwater streamflow throughout a 24-hour period. The wastewater discharges can vary from about 9 to $21 \mathrm{ft}^{3} / \mathrm{s}$ at Fargo to about 3 to $9 \mathrm{ft}^{3} / \mathrm{s}$ at Moorhead. If the estimated daily average wastewater discharge from Fargo and Moorhead is about $23 \mathrm{ft}^{3} / \mathrm{s}$ and the headwater streamflow is $50 \mathrm{ft}^{3} / \mathrm{s}$, the dilution ratio will be $1: 2.2$. If the headwater streamflow is $30 \mathrm{ft}^{3} / \mathrm{s}$, the dilution ratio will be $1: 1.3$. In order to appropriately simulate these conditions, the DAFLOW/BLTM unsteady-state model is proposed for this study.

The DAFLOW model (Jobson, 1989) routes unsteady streamflow by using an abbreviated form of the dynamic flow equation. The BLTM model (Jobson and Schoellhamer, 1987) is a one-dimensional transport model based on the Lagrangian reference frame in which the computational nodes move with the flow. Both models are products of the U.S. Geological Survey. The BLTM model simulates reaction kinetics that are similar to those used by the code in the Environmental Protection Agency's QUAL2E model by linking to a subroutine called "QUAL2E". The DAFLOW/BLTM model that will be used in this study was modified to represent periphyton concentration as a bed source. A sink term with a magnitude proportional to the growth and respiration rate determined for phytoplankton also was added for dissolved oxygen and nutrients. The DAFLOW/BLTM model is a fully dynamic model that simulates flow and water-quality conditions that vary with time and space.

Data collection was designed so that the Environmental Protection Agency's QUAL2E model, which was used during the 1989-90 study, could be calibrated. However, unlike the DAFLOW/BLTM model which calibrates transient storage separately from streamflow, the QUAL2E model does not account for transient storage and assumes instantaneous and complete mixing in each model reach. Given the pool-and-riffle channel configuration that is expected at drought streamflow, transient storage may be a consideration because the pools and riffles may affect the hydraulics of the stream. Thus, use of the QUAL2E model may result in inaccurate estimates of velocities, depths, and cross-section areas.

The calibrated and verified DAFLOW/BLTM model integrates water-quality conditions and processes that are involved with waste-assimilation capacities. The model will be used to simulate the effects of continuous treated-wastewater discharges to the Red River at drought streamflow. Waste loads that have been allocated to Fargo and Moorhead will be simulated in order to determine the effect on water quality relative to standards for the Red River in the 30.8-mi study reach.

Specific conductance, temperature, dissolved oxygen, 5- or 20-day carbonaceous biochemical oxygen demand, total nitrogen (organic, ammonia, nitrite, nitrate), total orthophosphorus, total phosphorus, and phytoplankton as chlorophyll $a$ values will be simulated. In order to achieve diurnal changes in dissolved-oxygen concentration, the DAFLOW/BLTM and QUAL2E models require selected meteorological data that are available from the local office of the National Weather Service. Simulated concentration versus time and distance illustrations will be prepared. To compare the measured and simulated values, measured concentrations will be displayed on these simulated concentration versus time and distance illustrations.

\section{WORK PLAN TO CALIBRATE AND VERIFY A WATER-QUALITY MODEL}

This section identifies and discusses the various work elements needed for accomplishing the data-collection for the study. The work elements specify who will provide personnel, vehicles, instruments, and supplies needed during data collection. The data collection site locations and descriptions are shown in figure 2 along with the streets and roads that 
need to be travelled in order to arrive at a particular site. Site numbers, descriptions, and locations are listed in table 1. The work plan also contains an annual drought-formation monitoring plan that includes a 9-month time line that specifies when essential planning events must occur before actual project start up.

The project chief will be prepared to do any necessary training in the classroom and in the field. The type of training needed will depend on the amount of experience possessed by the personnel assigned to the project. Because sampling for this project is a one-time event, the work must be done right the first time. Therefore, a field demonstration of sample collection and preservation techniques is essential.

\section{Work Elements}

\section{Tracer-Sample Collection}

For initial planning, the study reach will be divided in two reaches for two tracer injections. During the actual study, three reaches and three injections may have to be used because traveltimes may be so slow that the gas tracer is depleted before it reaches the last sampling site. Dye concentrations will be measured using a field-calibrated fluorometer and plotted in the field while samples are being collected.

The objective of the dye sampling is to define, quantitatively and graphically, the passage of the entire dye cloud. Dye-sampling intervals can vary from 2 to 60 minutes, depending on the sharpness of the dye peak and the duration of the dye-cloud passage. The sharpness of the dye peak and the duration of the dye-cloud passage depends on the distance from the injection site to the sampling site. The closer the sampling site is to the injection site, the more frequently samples are collected. Conversely, the further the sampling site is from the injection site, the less frequently samples are collected. Dye sampling continues until background concentrations are reached or can be adequately estimated by extrapolation of plotted concentration data.

For efficient propane-gas absorption, a stream depth of about $2 \mathrm{ft}$ is required for gas-diffuser placement. Different types of rotameters and regulators dispense gas at different rates. The rotameters and regulators that will be used should be tank tested (calibrated) to determine the actual amount of gas-volume delivery at various settings. Calibrated instruments are the only way to be assured that a known volume of propane is being released into the stream. In order to confirm that the propane injection rate is adequate and accurate, test samples should be collected at the first downstream site and sent by "overnight" mail to the U.S. Geological Survey Laboratory in Ocala, Fla., for immediate analysis. The test-gas samples should be collected after the dye concentration has reached 2 percent of the peak dye concentration or $0.1 \mu \mathrm{g} / \mathrm{L}$, whichever is larger. The analyst Khank K. Doan (kkdoan@usgs.gov) should be contacted before the gas samples are collected so he can prepare to analyze the test samples immediately upon their arrival.

To plan tracer and synoptic sampling, various calculations are required for a given streamflow. Examples, of these calculations are given in supplements $1,5,6$, and 11. The assumed values for the calculations are: streamflow in the downstream reach ranges from 87 to $105 \mathrm{ft}^{3} / \mathrm{s}$, and associated velocities range from 0.52 to $0.59 \mathrm{ft} / \mathrm{s}$; streamflow in the upstream reach ranges from 60 to $87 \mathrm{ft}^{3} / \mathrm{s}$, and associated velocities range from 0.45 to $0.52 \mathrm{ft} / \mathrm{s}$; the average depth is $2.0 \mathrm{ft}$; the reaeration-rate coefficient $\left(\mathrm{K}_{2}\right)$ equals 1.8 from plot (Wesolowski, 1994); propane weighs 8.51 cubic feet per pound $\left(\mathrm{ft}^{3} / \mathrm{lb}\right)$; the propane-gas desorption rate coefficient $\left(\mathrm{K}_{\mathrm{p}}\right)$ equals $0.719 \mathrm{~K}_{2}$; and the assumed propane absorption efficiency was 5 percent. For more information and calculation results, see supplement 1 . At the time of the study, these calculations will have to be redone using the actual streamflow.

Typically, the downstream reach is injected first. In this case, the dye and gas tracers will be injected at site 9. A slug injection of 0.594 liter of rhodamine WT dye, 20-percent solution, will produce a $1-\mu \mathrm{g} / \mathrm{L}$ peak at site 14 . Dye samples will be collected at sites $9.5,10,12$, and 14. A commercial grade of propane gas injected at a constant rate of 4.5 pounds per hour (lbs/hr) [if the rotameter used to meter the propane gas is calibrated for air, this value will have to be adjusted to an air ratio (Kilpatrick and others, 1989, p. 21)] will produce a $1-\mu \mathrm{g} / \mathrm{L}$ peak at site 14 . Three diffusers are required, but four should be used to increase absorption efficiency. About 185 pounds of propane will be required for a traveltime of 41.22 hours. The type of rotameter and regulators used will determine the settings. Gas samples will be collected only at sites 9.5, 12, and 14 to meet residence requirements (Kilpatrick and others, 1989, p. 15). 


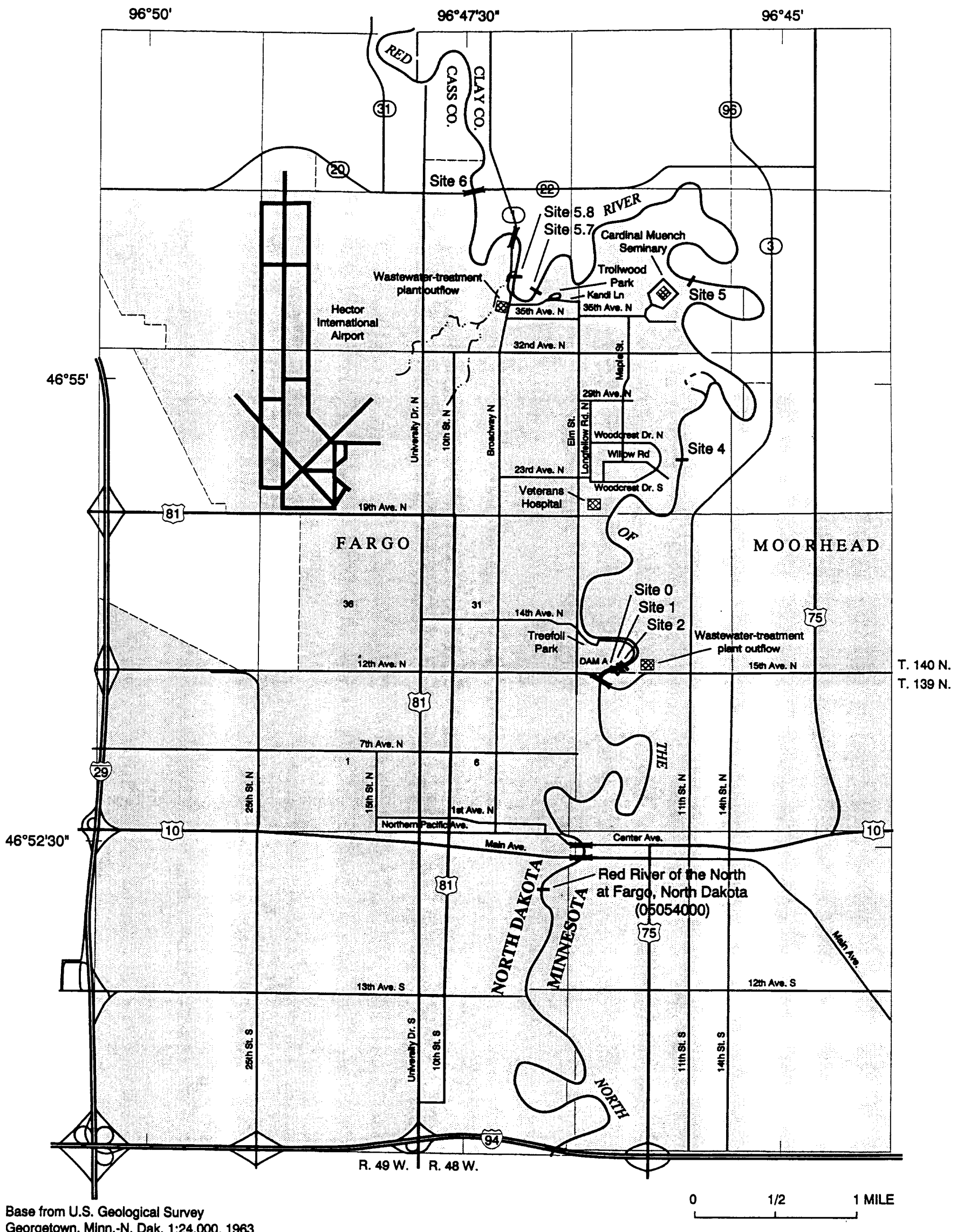

Georgetown, Minn.-N. Dak. 1:24,000, 1963

Fargo North, N. Dak.-Minn. 1:24,000, 1959

Photorevised 1971 and 1976, revised 1993

Figure 2. Location of data-collection sites on the Red River of the North from Fargo, North Dakota, and Moorhead, Minnesota, to Georgetown, Minnesota. 


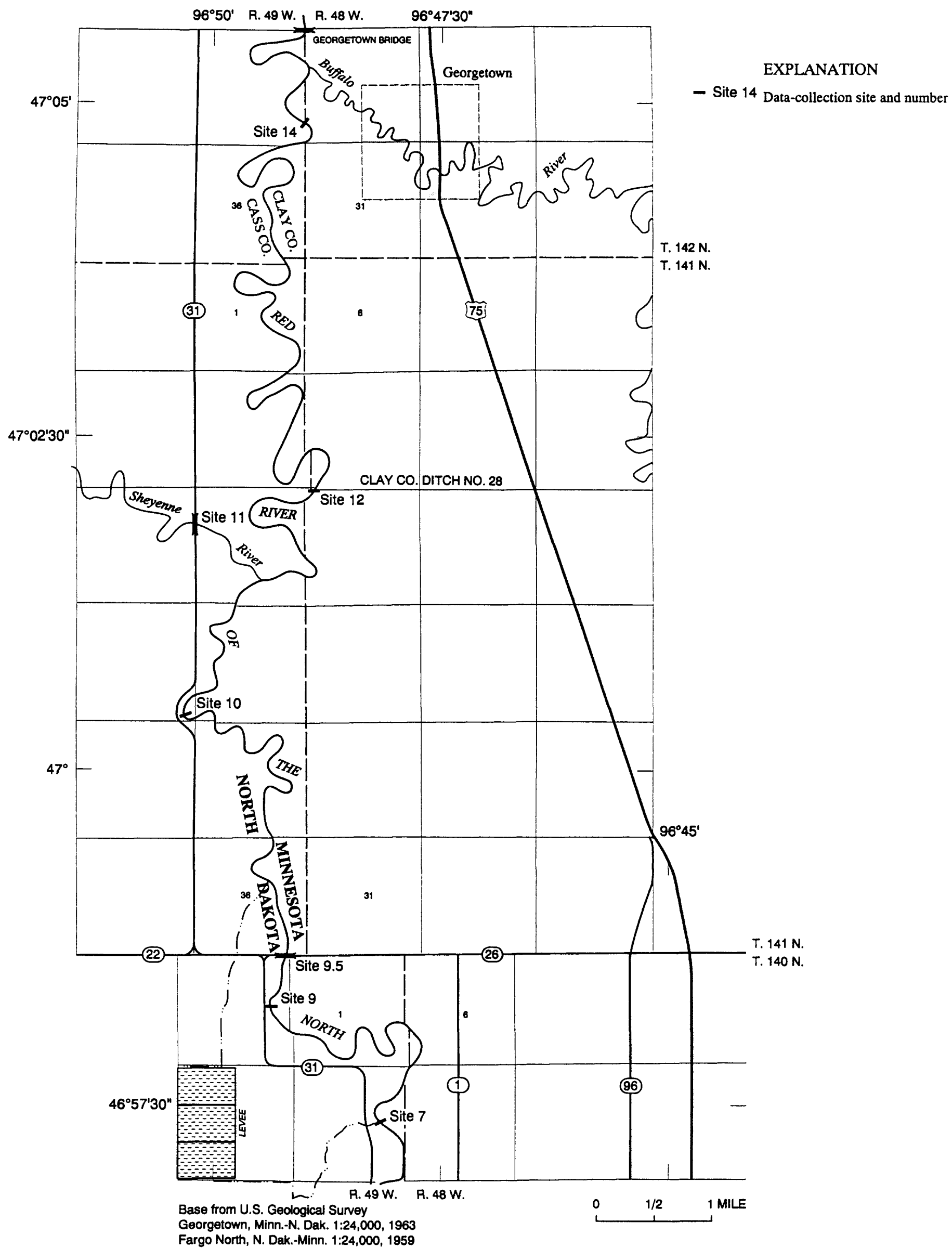

Figure 2. Location of data-collection sites on the Red River of the North from Fargo, North Dakota, and Moorhead, Minnesota, to Georgetown, Minnesota--Continued. 
The upstream reach is injected next. The dye and gas tracers will be injected at site 1 . A slug injection of 0.673 liter of rhodamine WT dye, 20 -percent solution, will produce a $1-\mu \mathrm{g} / \mathrm{L}$ peak at site 10 . Dye samples will be collected at sites 4 , $5,5.7,7,9.5$, and 10. A commercial grade of propane gas injected at a constant rate of $9.15 \mathrm{lbs} / \mathrm{hr}$ (this value is not adjusted for air) will produce a $1-\mu \mathrm{g} / \mathrm{L}$ peak at site 10 . Three diffusers are required, but four should be used to increase absorption efficiency. About 527 pounds of propane will be required for a traveltime of 57.83 hours. The type of rotameter and regulators used will determine the settings. Gas samples will be collected only at sites $4,5.7,7$, and 10 to meet residence requirements.

The major required instruments and equipment are diffusers, fluorometers, and samplers. The remaining needed equipment and supplies are listed in "supply inventory" lists that will be discussed later. The U.S. Geological Survey North Dakota District owns four Wilfley Webber diffusers. These diffusers presently (March 2000) have been used only once, in the Ardmore, Okla., study in 1997, and are in excellent condition. The diffusers were purchased in May 1997. The diffuser ceramic-tile area is 2.5 by 25 inches for a total of 62.5 square inches. The U.S. Geological Survey North Dakota District owns one Turner Designs model 10 fluorometer. This model or a newer model is preferred for dye-concentration measurements. Three fluorometers are required for the dye study (two will be used by the sampling crews and one will be used as a backup). The North Dakota District has one fluorometer, and the remaining two fluorometers will have to be borrowed. One can be borrowed from the U.S. Geological Survey Florida District, and the other can be borrowed from the U.S. Geological Survey Missouri District. The contact person in the Florida District is Bill McBride (wmcbride@usgs.gov; phone number 352-237-5514, extension 213), and the contact person in the Missouri District is Don Wilkinson (wilkinson@usgs.gov; phone number 816-254-2942). The propane-gas samplers are a non-aerating type. Two sets of two samplers (two bottles are collected at a time) are required. The dye samplers are made from angle iron and the bottles are held in place with heavy-duty rubberbands. As an alternative, the dye samples could be collected simultaneously with the gas samples. The dye-sample bottles are strapped to the outside of the gas samplers and are held in place with heavy-duty rubberbands.

A total of 15 people and 8 vehicles will be needed to conduct the tracer sampling. The 15 people include a project leader, a 2-person discharge-measuring crew, an 8-person tracer-sampling crew, a 2-person tracer-injection crew, and 2 backups. The discharge-measuring crew will be divided into two 1-person teams. Each team will work a 12-hour shift. The discharge-measuring crew will need one U.S. Geological Survey vehicle equipped for discharge measurements and one cooperator vehicle for transportation. The tracer-sampling crew will be divided into four 2-person teams. Each team will work a 12-hour shift. The tracer-sampling crew will need two U.S. Geological Survey vehicles equipped for water-quality sampling and two cooperator vehicles for transportation. The tracer-injection crew will be divided into two 1-person teams. Each team will work a 12-hour shift. The tracer injection crew will need one U.S. Geological Survey four-wheel-drive vehicle and trailer for hauling equipment and one cooperator vehicle for transportation.

Training will be required for U.S. Geological Survey and cooperator personnel. The training will be held in the classroom and in the field. Tracer-sampling instructions are given in supplement 2.

Supply inventories, schedules, and data forms are necessary in order to successfully complete the tracer-sample collection. A list of the supplies and equipment needed by the tracer-injection crew is given in supplement 3 . The list will need to be updated from slug injection to constant-rate injection for this study. A list of the supplies and equipment needed by the tracer-sampling crew is given in supplement 4 . The list will need to be updated for this study. Examples of the dye-sampling schedules are given in supplements 5 and 6 . The examples contain estimates of the arrival times of the dye-cloud leading edge, peak, and trailing edge. An example of the tracer sampling field-sample note sheet is given in supplement 7. The note sheets are needed in order to have uniform and complete entries of tracer data.

\section{Hydraulics}

The calibration of hydraulic-geometry exponents and coefficients can be accomplished by several methods (Jobson, 1989, p. 52-53). Hydraulic-geometry exponents and coefficients will be calibrated using data from two existing traveltime studies (Wesolowski, 1994), data from two planned traveltime data sets collected in this study, and the relation between channel width, depth, and streamflow. To establish a relation between channel width, depth, and streamflow, streamflow measurements should be made at about $1,000,400,200,100$, and $50 \mathrm{ft}^{3} / \mathrm{s}$. These streamflow measurements will be made at sites 1, 9.5, and 14. Additional top widths and areas will be measured at these streamflows at sites 5, 7, 10 , and 12 . 
Geometry exponents and coefficients calculated by this method may produce unrepresentative wave speeds (Harvey Jobson, U.S. Geological Survey, oral commun., 1999). However, because the model is planned for drought streamflows, the error introduced by the unrepresentative wave speeds should not be significant.

The hydraulic part of the Environmental Protection Agency's QUAL2E model can be calibrated using either discharge coefficients or trapezoidal cross sections. The discharge coefficients usually are determined from stage-discharge rating curves. However, rating curves are not available for the study reach. Therefore, it is assumed that with some modification the discharge coefficients can be obtained from the same data that will be used to calibrate the DAFLOW model. If this assumption proves to be incorrect, the hydraulic part of the QUAL2E model will be calibrated using trapezoidal cross sections. Trapezoidal cross sections will be determined from channel cross-section data. Channel cross sections will be measured at each 1/2-mi interval if time permits. Otherwise, a 1-mi interval will be used. The depth will be measured at 2to 3-ft increments of width. For transforming the cross section into trapezoidal cross sections, cross-section measurements will extend up the bank 5 to $10 \mathrm{ft}$ to get an estimate of slope. The edge of the water will be noted. This work will be done by the teams at various times during the study when they are not collecting samples.

A light boat or canoe, topographic sheets, and discharge-measuring equipment are needed to make cross-section measurements. Access to the river is a problem in the study reach, and there are few places to launch a boat. The location of the cross sections will be estimated from topographic sheets or by using global positioning system instrumentation. Associated discharge measurements will be made at the time cross-section measurements are made. Streamflow will be measured at sites 1, 9.5, and 14. Three bridges cross the river in the study reach; therefore, it should be possible to get an estimate of the water-surface slope. Elevations and locations of benchmarks on the bridges need to be determined before the study. The water-surface slope will be affected when pools and riffles begin to form in the channel.

\section{Sediment-Oxygen-Demand Measurements}

Two people and two vehicles will be needed to make the sediment-oxygen-demand measurements. Of the two people, one--probably the project leader--will be from the U.S. Geological Survey, and the other will be from the cooperating agency. The vehicles will be a U.S. Geological Survey four-wheel-drive vehicle and trailer to carry equipment and a cooperator vehicle for transportation. The U.S. Geological Survey North Dakota District owns four low-profile benthic chambers, which are also called respirometers, for measuring sediment oxygen demand. The benthic chambers are suitable for placement in relatively shallow low-streamflow rivers. Three of the chambers are open bottomed, and one chamber is close bottomed. Extra water-circulation motors are absolutely essential because of motor failure. The present (September 28, 1999) inventory list shows three spare motors. All motors need to be tested to verify that they are operating properly. Necessary supplies that are not listed on the supply list are various-sized rubber stoppers that will be used to evacuate air from the chamber. Equipment that will be needed includes four 12-volt, wet-cell batteries that will be used to power water-circulation motors; one backup battery; two battery chargers; five portable dissolved-oxygen meters (with stirring capability); three backup meters (one meter for each chamber and one for measuring instream dissolved oxygen); a barometer; and a thermometer. The cables for the dissolved-oxygen probes should be $50 \mathrm{ft}$ long and equipped with stirrers. There should be three backup cables and probes. An adequate supply of dissolved-oxygen probe membranes and solution is necessary. The U.S. Geological Survey North Dakota District has two recording dissolved-oxygen meters. The other required meters are portables currently in the North Dakota District inventory that can be made available to this study.

Forms to record sediment-oxygen-demand measurements are needed in order to have uniform and complete entires of measurement data. An example of the measurement sheet is given in supplement 8. Forms to record dissolved-oxygen recorder information also are needed. An example of the respirometer dissolved-oxygen note sheet is given in supplement 9. A list of the supplies and equipment needed for sediment-oxygen-demand measurements is given in supplement 10 . The list will need to be updated for this study.

\section{Periphyton}

If periphyton are determined to be significant to the dissolved-oxygen budget, a literature search will need to be done on the best way to collect samples, the instrumentation needs, and the supply needs. 


\section{Synoptic Water-Quality Sample Collection}

The sample-collection schedule for the Lagrangian reference frame assumes streamflows of $60 \mathrm{ft}^{3} / \mathrm{s}$ (site 1 ) to $105 \mathrm{ft}^{3} / \mathrm{s}$ (site 14). These streamflows include municipal effluent and flows from the Sheyenne River. Associated velocities range from 0.45 to $0.59 \mathrm{ft} / \mathrm{s}$. Synoptic water-quality samples will be collected at 2-hour intervals at sites 1,2 , and 5.8 and 3-hour intervals at sites 4, 5, 5.7, 7, 9,10,11,12, and 14 (see proposal for when the 2- and 3-hour intervals may be changed to 3-and 4-hour intervals.) The synoptic water-quality sampling schedule is given in supplement 11.

A total of 27 people and 8 vehicles will be needed to conduct the synoptic water-quality sampling. Twenty-four people will be divided into a synoptic water-quality sampling crew, a discharge-measuring crew, a dye-concentration measuring crew, and an alkalinity crew. Two people will be used as backups and one will be the project leader.

Synoptic water-quality sampling will require 16 people. The 16 people will be divided into four 4 -person crews, and each of the four crews will be subdivided into two 2-person teams. Four of the 2-person teams will work a 12-hour shift at a time. Each of the 4-person crews will need one U.S. Geological Survey vehicle for sampling water quality and one cooperator vehicle for transportation. Therefore, the synoptic water-quality sampling crew will need four U.S. Geological Survey vehicles for sampling water quality and four cooperator vehicles for transportation.

The discharge-measuring crew will consist of two people. The two people will be divided into two 1-person teams. Each team will work a 12-hour shift. The discharge-measuring crew will need two U.S. Geological Survey vehicles equipped for making discharge measurements.

The dye-concentration-measuring crew will consist of four people. The four people will be divided into two 2-person teams. Each team will work a 12-hour shift. The dye-concentration-measuring crew will need one vehicle equipped for making dye-concentration measurements and one vehicle for transportation.

The alkalinity-measuring crew will consist of two people. The two people will work as needed in a central location. The alkalinity-measuring crew will need one vehicle. The vehicle can be either a U.S. Geological Survey or a cooperator vehicle. The U.S. Geological Survey project chief will need one full-size U.S. Geological Survey four-wheel-drive sport utility vehicle.

A Hydrolab or a similar multiparameter water-quality meter will be used to measure the field-analyzed constituents. Each of the four crews will need one meter, and one spare meter will be needed for a backup for a total of five meters. The meters should be calibrated before the beginning of the synoptic water-quality sampling and periodically checked for calibration at the beginning of each shift change. After initial calibration, a test sample should be measured using all five meters. The measured values of specific conductance, $\mathrm{pH}$, temperature, and dissolved oxygen produced by each meter should be recorded and compared. All of the measured values should be within acceptable error. If the measured values are not within acceptable error, the meters should be recalibrated or reconditioned if needed.

The U.S. Geological Survey, North Dakota District, office in Bismarck has two Hydrolabs and the field office in Grand Forks has one Hydrolab assigned to the U.S. Geological Survey National Water-Quality Assessment program. The contact person in the Grand Forks office is Kelly Boespflug (klboesf@usgs.gov), and the contact people for the National Water Quality Assessment program (Minnesota District) are Mark Brigham (mbrigham@usgs.gov) and Dave Lorenz, Chief of the National Water-Quality Assessment program (lorenz@usgs.gov). In addition to the three Hydrolabs, a DataSonde or similar multiparameter water-quality meter may need to be rented to collect data from the pool upstream from site 1 . The multiparameter meter calibration sheet is given in supplement 12. The WRD surface-water quality field-note sheet (BQA-1 3/92) is used to record field data. For constituents analyzed in the U.S. Geological Survey Central Laboratory in Ocala, Fla., the laboratory schedules, bottle types, required volumes, and sample treatments will be determined when the study is underway. For samples sent to the North Dakota Department of Health Laboratory, the necessary forms will be provided by the North Dakota Department of Health when the study is underway. Alkalinity will be determined in the field at a central location and computed on surface-water quality field-note sheets (BQA-1 3/92).

Each sampling crew will need a supply-and-equipment list of all the bottles, preservatives, processing equipment, supplies, coolers, etc. The bottles needed for each sample can be placed into a Ziplock bag for convenience. A list of the supplies and equipment needed by the synoptic water-quality sampling crews is given in supplement 13 . The list will need to be updated for this study. 


\section{WORK PLAN TO MONITOR DROUGHT FORMATION}

This section discusses drought indices that need to be monitored in order to provide early warning that conditions are favorable to produce drought streamflow. To establish a baseline, historic values for some of the drought indices for selected years were reviewed. An annual review of the drought indices is recommended. The review would be summarized in an annual report. If the annual review indicates conditions are favorable to produce drought streamflow, a time line for putting the study in motion is provided.

\section{Review of Selected Historical Drought Indices}

Drought indices reviewed, or recommended for review, are hydrographs, the crop-moisture index, the Palmer Hydrological Drought Index, precipitation, and drought moisture. Hydrographs for years with drought streamflows for the Red River of the North at Fargo, N. Dak., gaging station (05054000) for April through September during 1942-94 were reviewed. The following 10 years were reviewed: 1960, 1961, 1963, 1964, 1976, 1977, 1981, 1987, 1988, and 1989 (hereinafter referred to as the 10 low-flow years) (figs. 3-9). In addition, 1975, 1980, and 1986 were included in the figures for the purpose of comparing the hydographs before the year of interest. Data for the 10 low-flow years were examined to characterize streamflow recession after spring runoff. Based strictly on streamflow, the earliest indication of a low-flow year is in April when spring runoff usually begins. Typically, daily mean streamflows during the 10 low-flow years are within a range of 1,000 to $3,000 \mathrm{ft}^{3} / \mathrm{s}$ during spring runoff. In some low-flow years, the daily means do not exceed $1,000 \mathrm{ft}^{3} / \mathrm{s}$. In all years reviewed except 1989 , streamflows were $1,000 \mathrm{ft}^{3} / \mathrm{s}$ or less by May 1 . Typically, the recessional mean daily discharge did not reach $100 \mathrm{ft}^{3} / \mathrm{s}$ until about August 1 but can occur as early as July 1 (1988) or as late as August 31 (1986). Therefore, to collect samples when headwater streamflow is $100 \mathrm{ft}^{3} / \mathrm{s}$ or less, project planning should be completed before July 1 .

In 5 of the 10 low-flow years, streamflow increased in September. Therefore, data collection should be planned to take place before the end of August. Thus, the sampling-opportunity window is about July 1 through August 31 . When above-normal June rain occurred in some of the 10 low-flow years, the recession was deferred. In these cases, the sampling-opportunity window for study implementation will be reduced during July and August.

A comparison was made of the July through September streamflows for the 10 low-flow years in the reach from the Otter Tail River below Orwell Dam near Fergus Falls, Minn., gaging station (05046000) to the Red River of the North at Fargo, N. Dak., gaging station (05054000) (figs. 10-14). In some years, the effects of water releases by the U.S. Army Corps of Engineers according to their drought-conditions plan clearly are evident as exhibited by the uniformity of the hydrograph. No consistent relation was evident between the amount of water released from Orwell Dam and the amount that reached Fargo. In general, when the releases were $100 \mathrm{ft}^{3} / \mathrm{s}$ or less, there was a loss of streamflow between Orwell Dam and Fargo. At times, however, when streamflow remained constant at Orwell Dam, there was a gain at Fargo, which probably was from precipitation in tributary basins downstream from Orwell Dam. The traveltime at $100 \mathrm{ft}^{3} / \mathrm{s}$ is about 5 to 6 days, and the traveltime at $30 \mathrm{ft}^{3} / \mathrm{s}$ is about 6 to 7 days.

The historic crop-moisture index was not reviewed for this report. However, a review of the index is recommended during annual review of the drought indices.

The Palmer Hydrological Drought Indexes for North Dakota climatic division 06 (ND-06) and Minnesota climatic division 04 (MN-04) for 1895-1999 were reviewed (figs. 15 and 16). The indices periodically show positive or negative values during an entire year for several consecutive years. Although a thorough study of comparing streamflow to the Palmer Hydrological Drought Indexes was not done, some generalizations can be made to provide helpful information regarding the likelihood of drought streamflow occurring in a given year. The indices for the 10 low-flow years indicated that the indexes ranged from about -1 to -7 . In all years preceding the 10 low-flow years except for 1987 (ND-06) and 1963 (MN-04), the index was negative or became negative in both divisions. The implication of this trend is that the Palmer Hydrological Drought Index could indicate drought streamflows when a negative index continues into the following year.

Historic precipitation was not reviewed for this report. However, a review of the historic precipitation (including snowfall) departures from normal for ND-06 and MN-04 is recommended during annual review of the drought indices. 


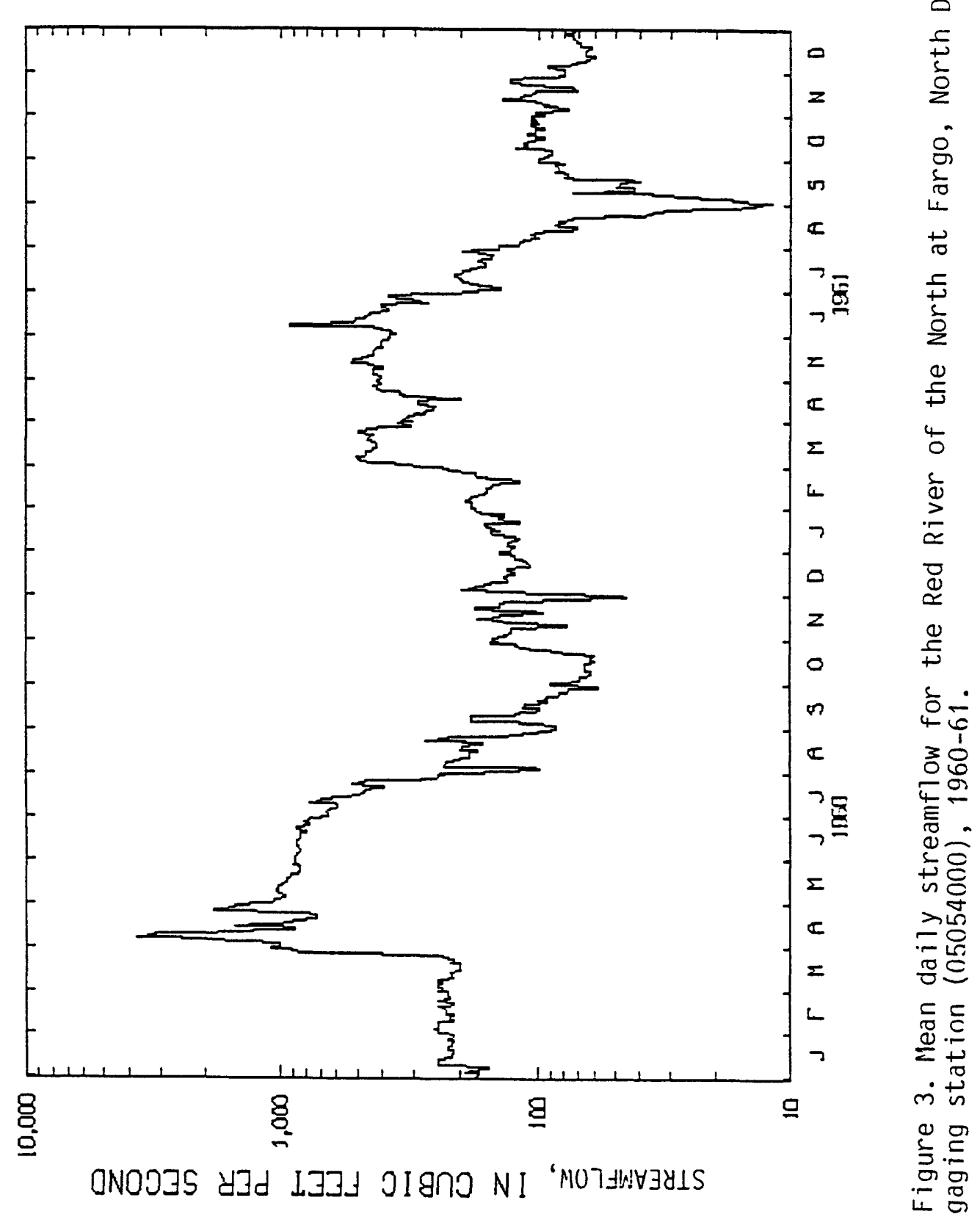




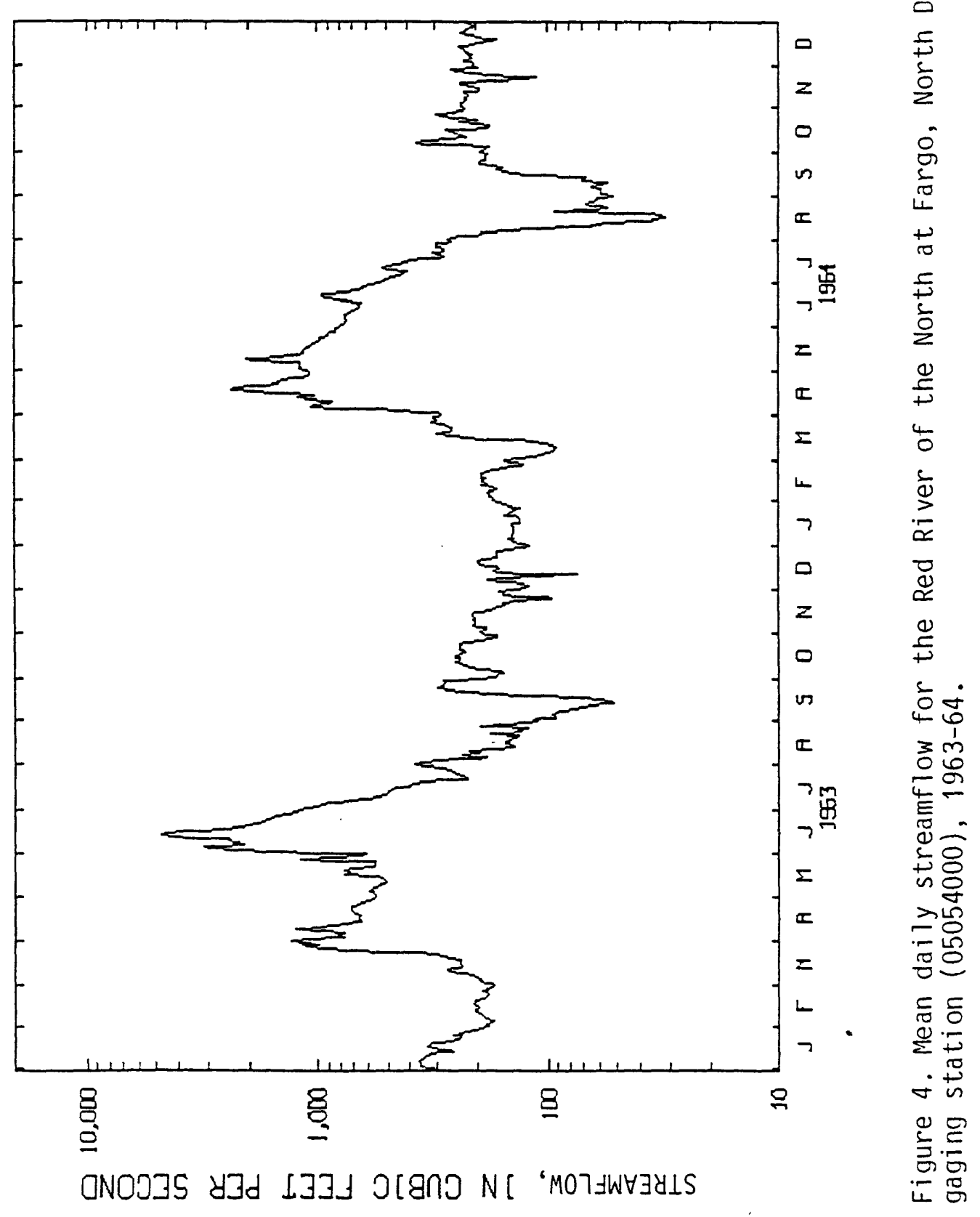









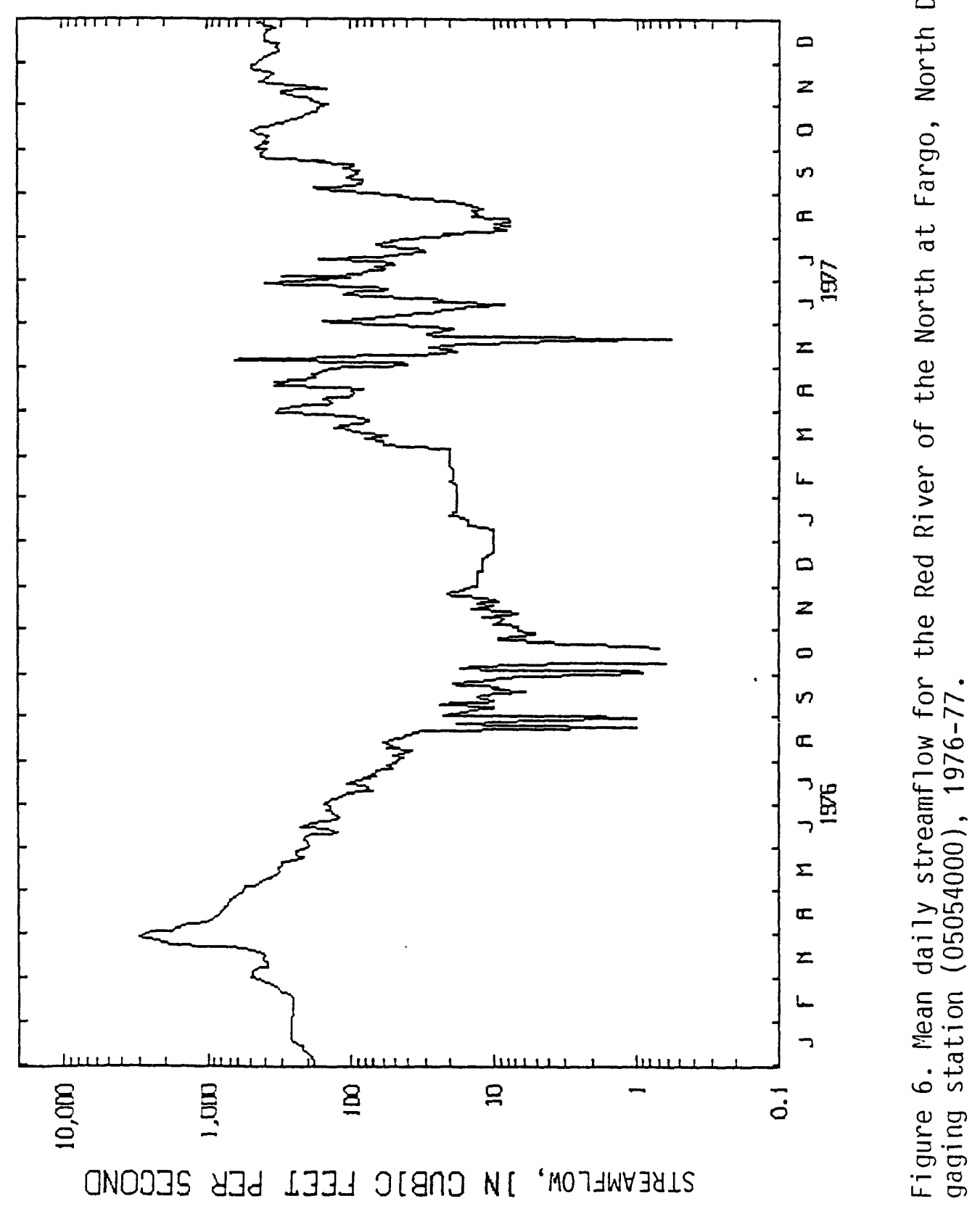




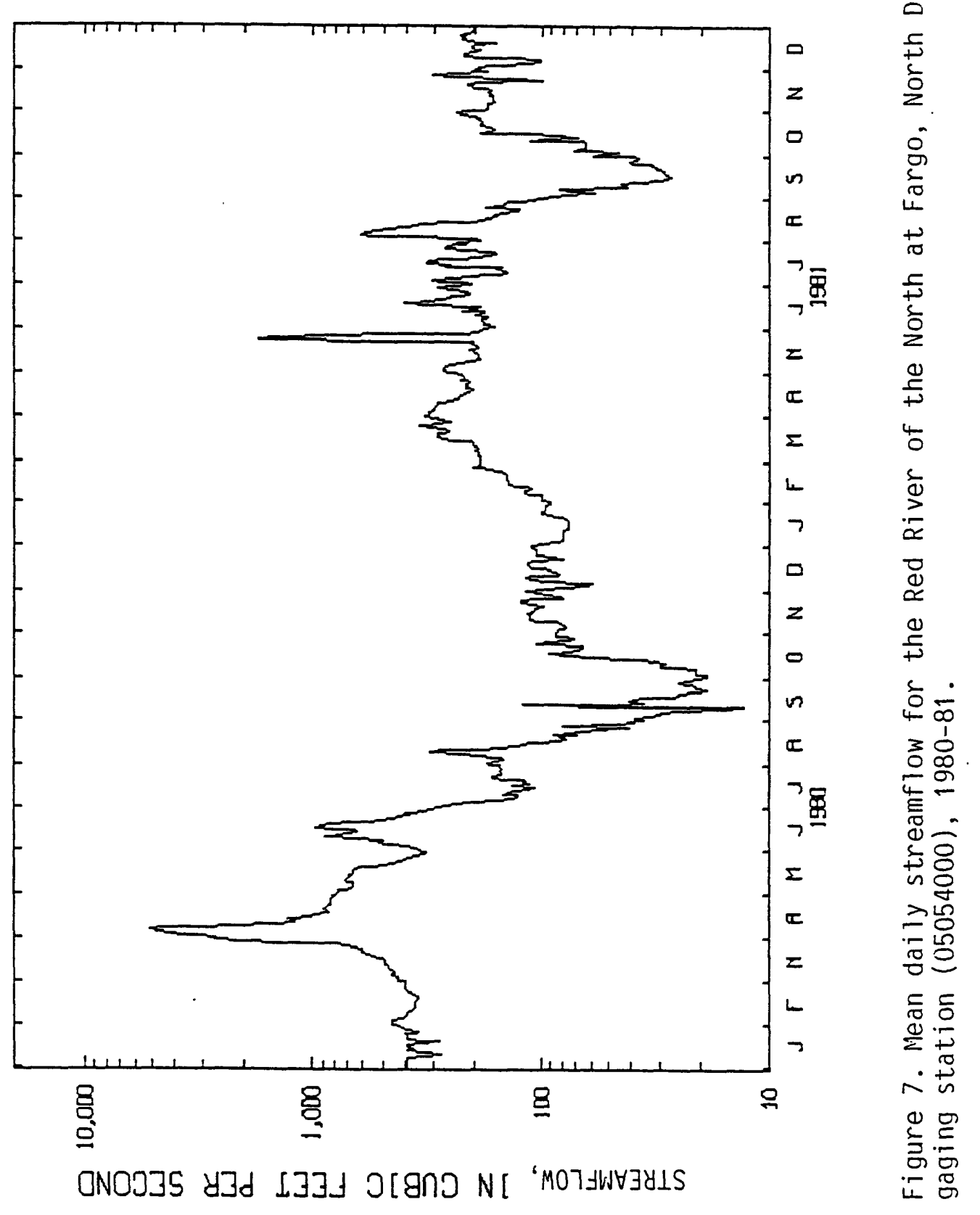




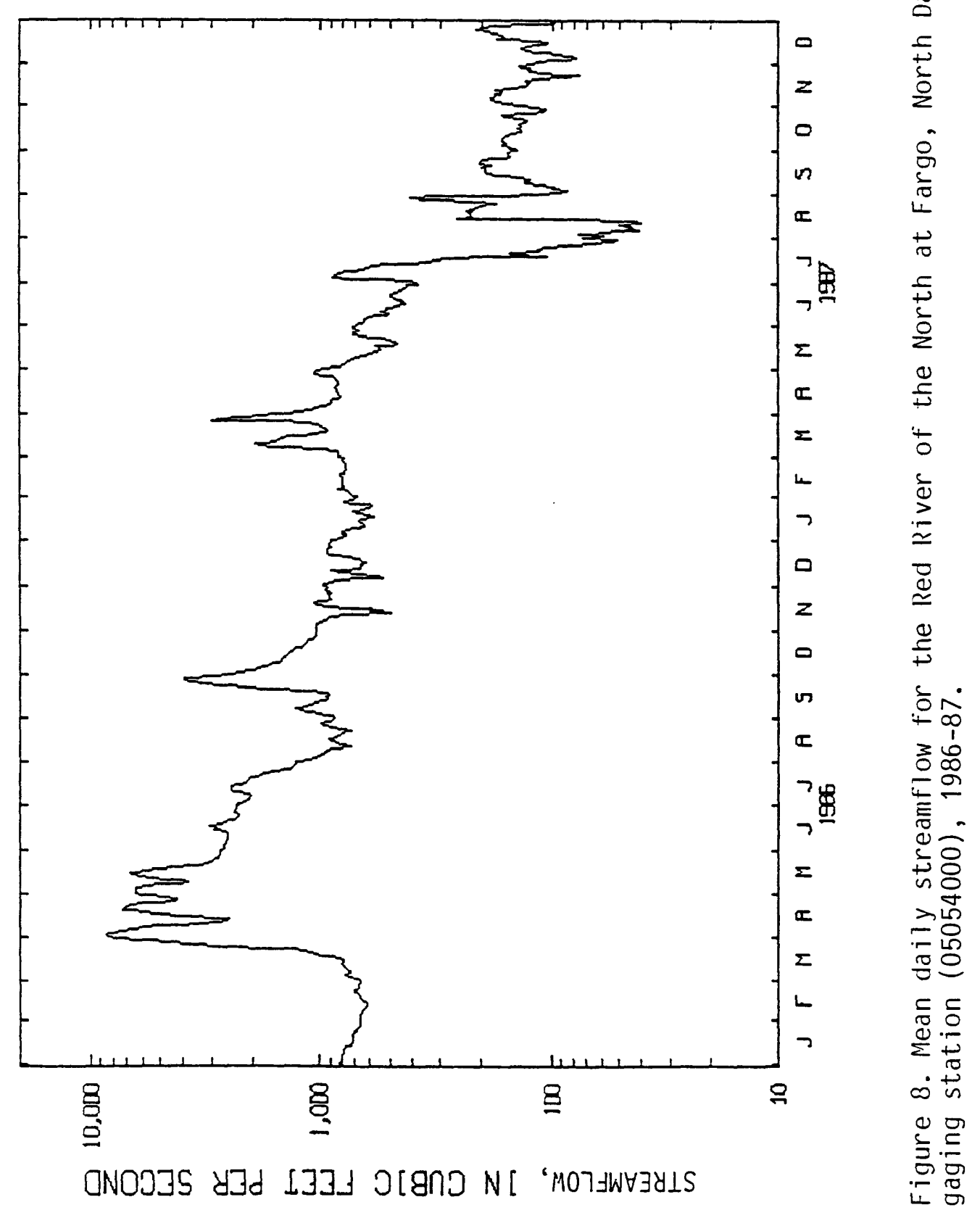




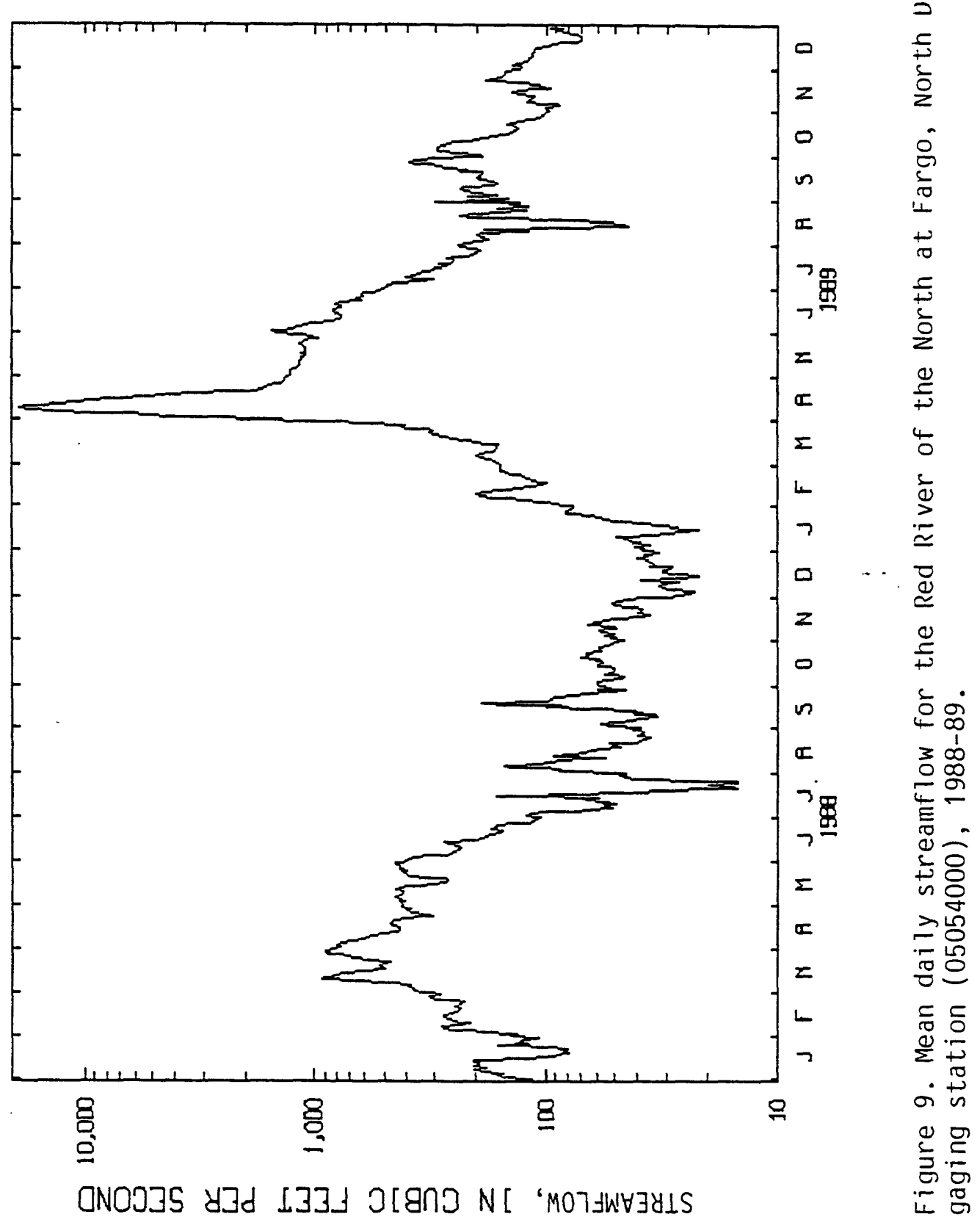




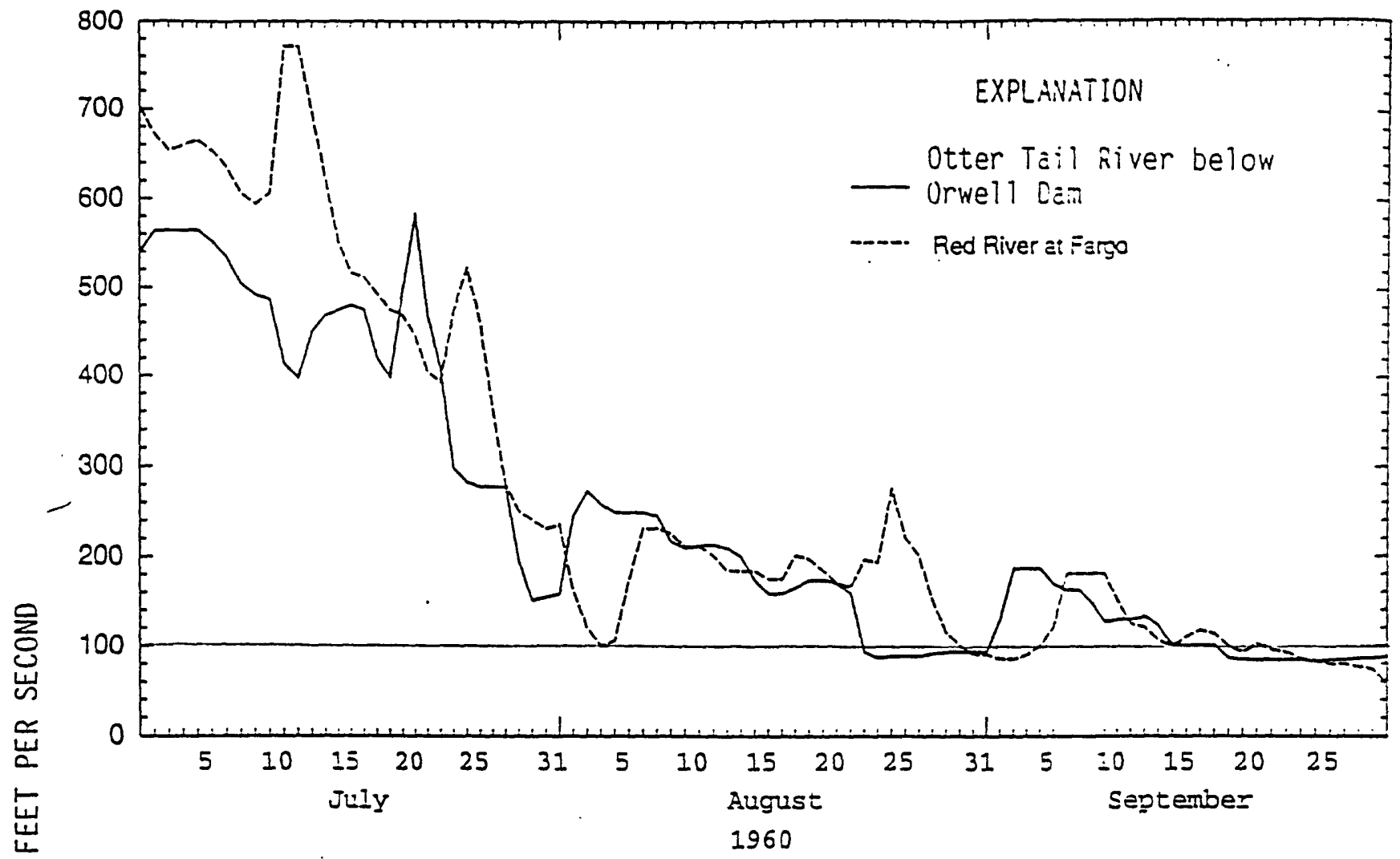

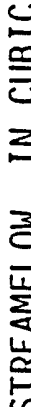

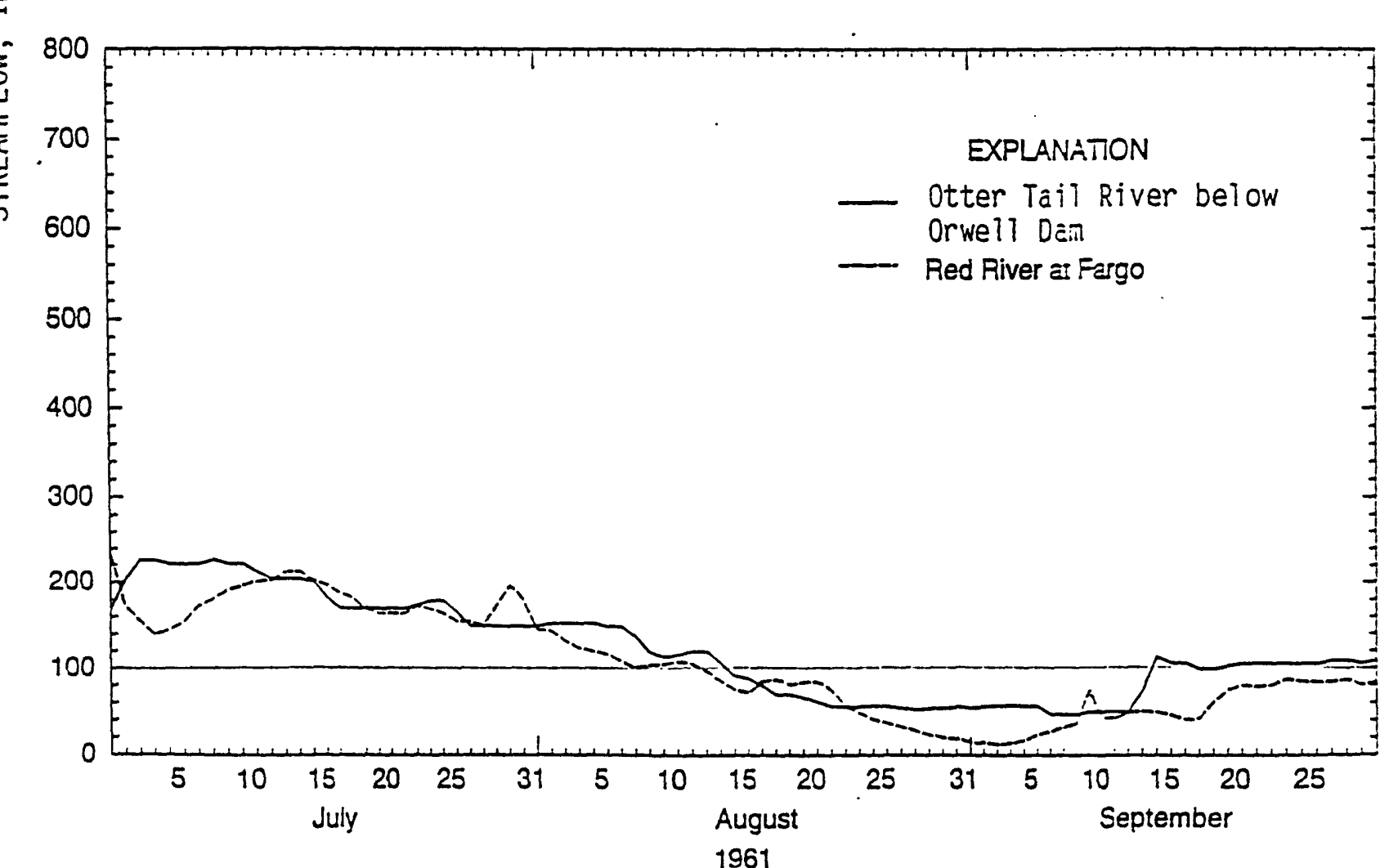

Figure 10. Mean daily streamflow for the Otter Tail River below Or'well Dam near Fergus Falls, Minnesota (05046000), and Red River of the North at Fargo, North Dakota (05054000), gaging stations, July through September 1960 anc 1961. 


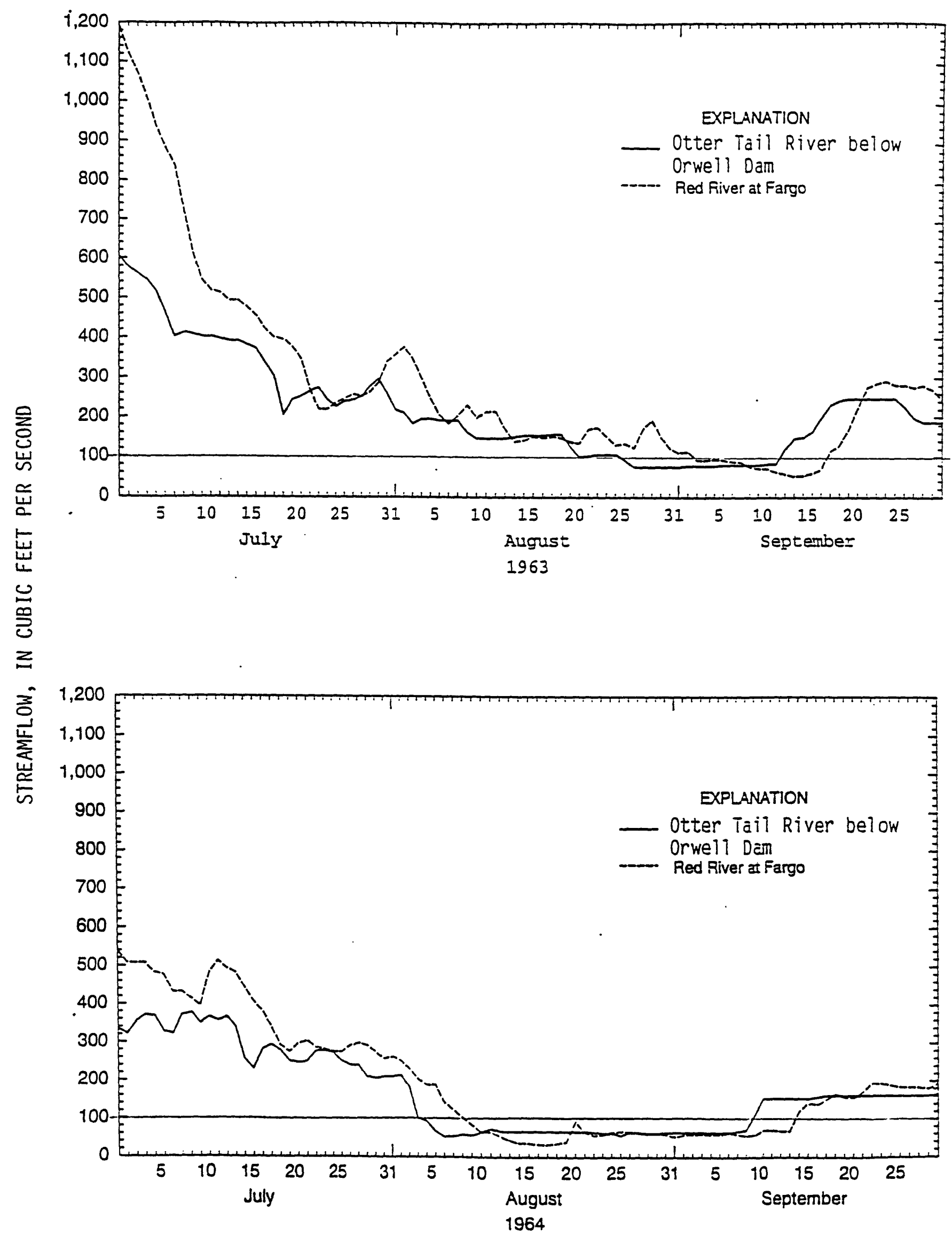

Figure 19. Mean daily streamflow for the Otter Tail River below Orwell Dam near Fergus Falls; Minnesota (05046000), and Red River of the North at Fargo, North Dakota (05054000), gaging stations, July through September 1963 and 1964. 


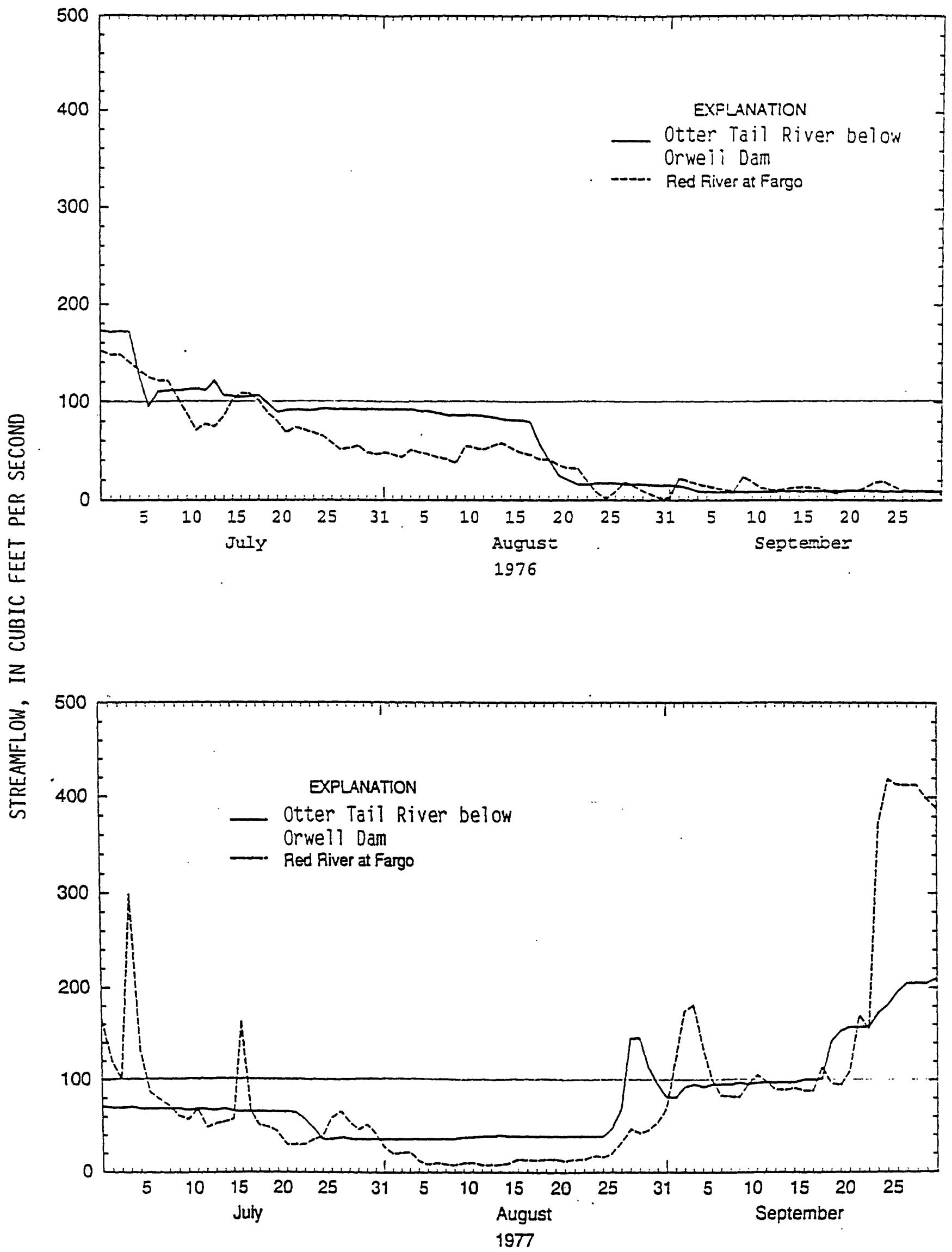

Figure 12. Mean daily streamflow for the Otter Tail River below Orwell Dam near Fergus Falls, Minnesota (05046000), and Red River of the North at Fargo, North Dakota (05054000), gaging stations, July through September 1976 and 1977. 


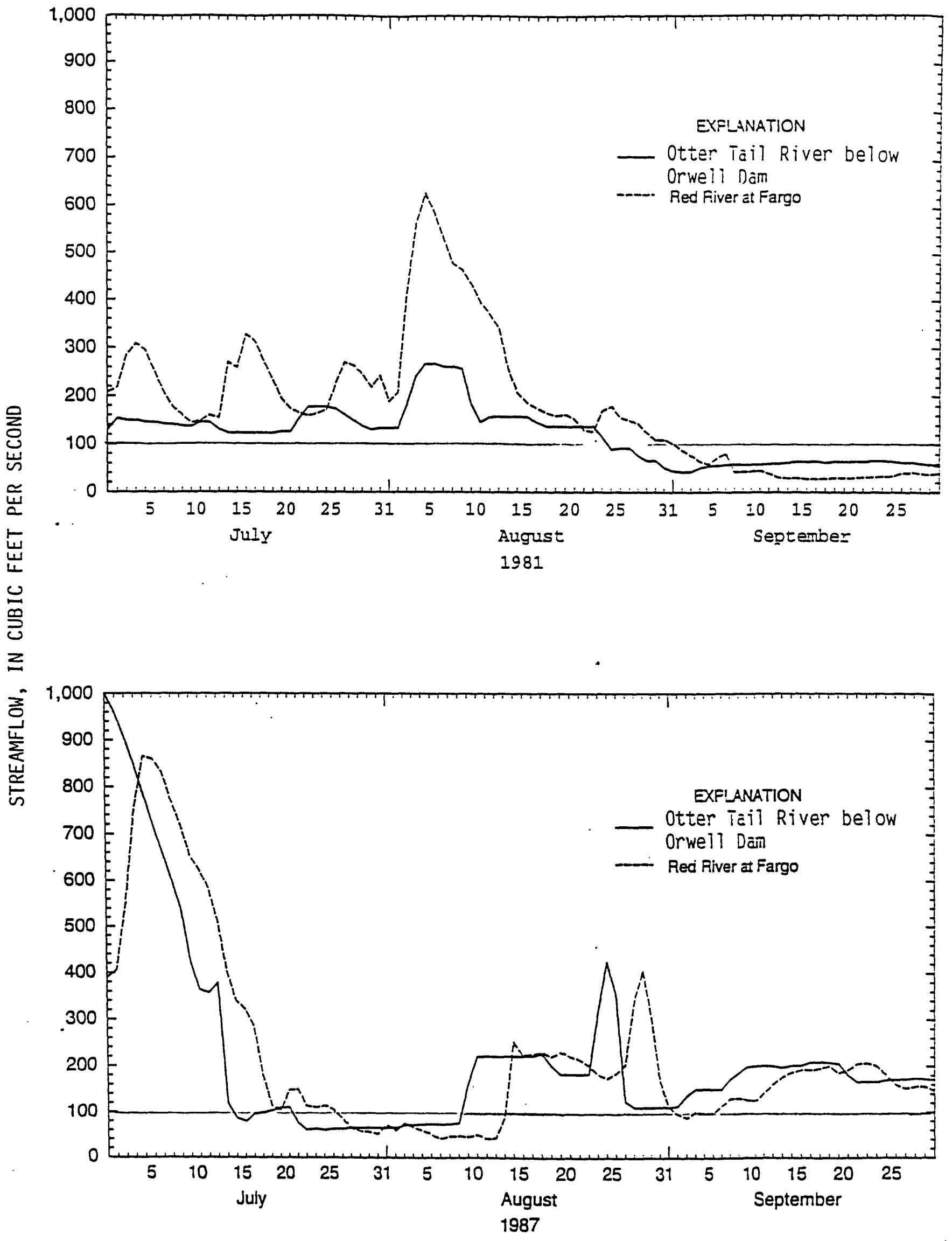

Figure 13. Mean daily streamflow for the Otter Tail River below Orwell Dam near Fergus Falls, Minnesota (05046000), and Red River of the North at Fargo, North Dakota (05054000), gaging stations, July through September 1981 and 1987. 


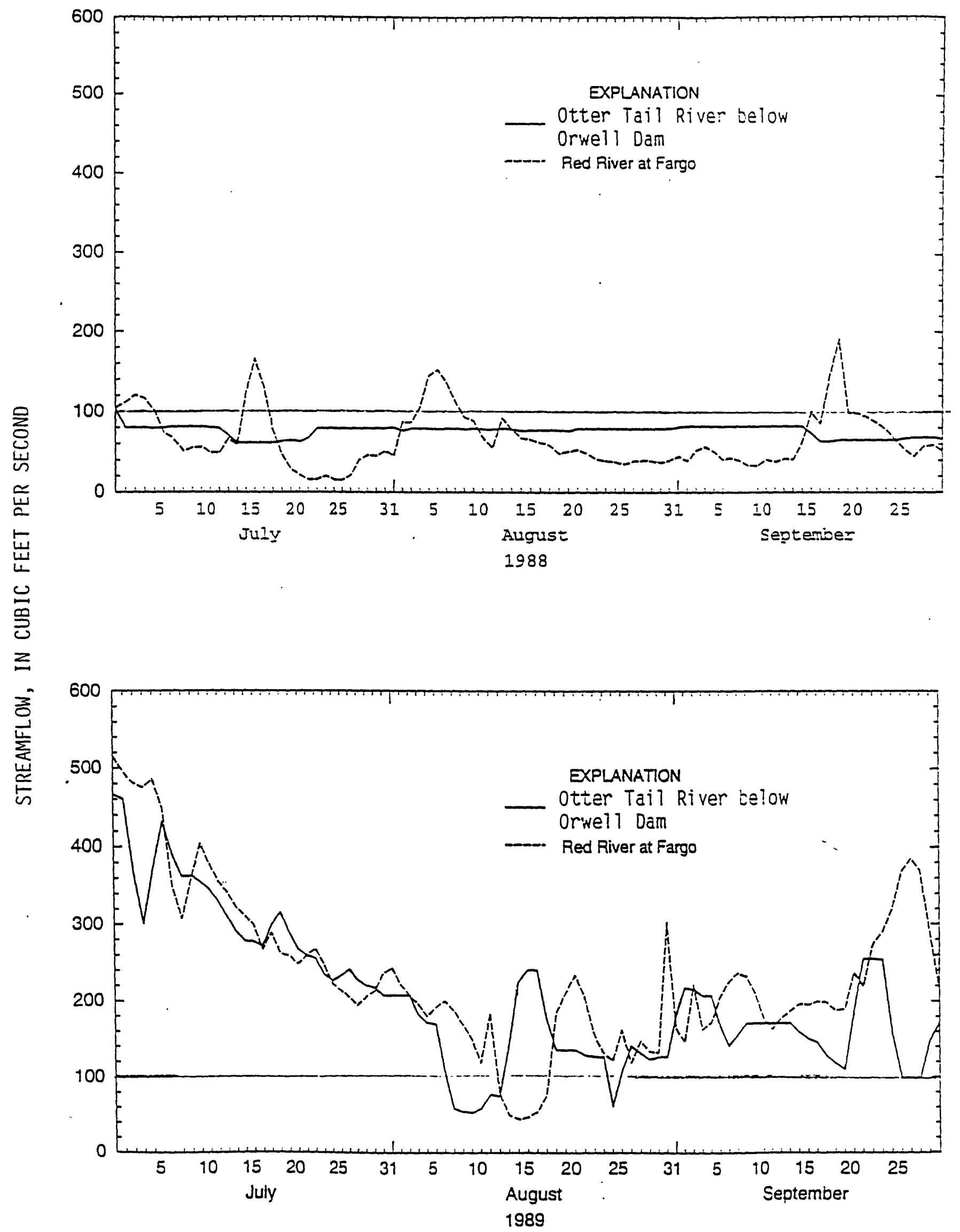

Figure 14. Mean daily streamflow for the Otter Tail River below Or'weil Dam near Fergus Falls, Minnesota (05046000), and Red River of the North at Fargo, North Dakota (05054000), gaging stations, July through September 1988 and 1989. 






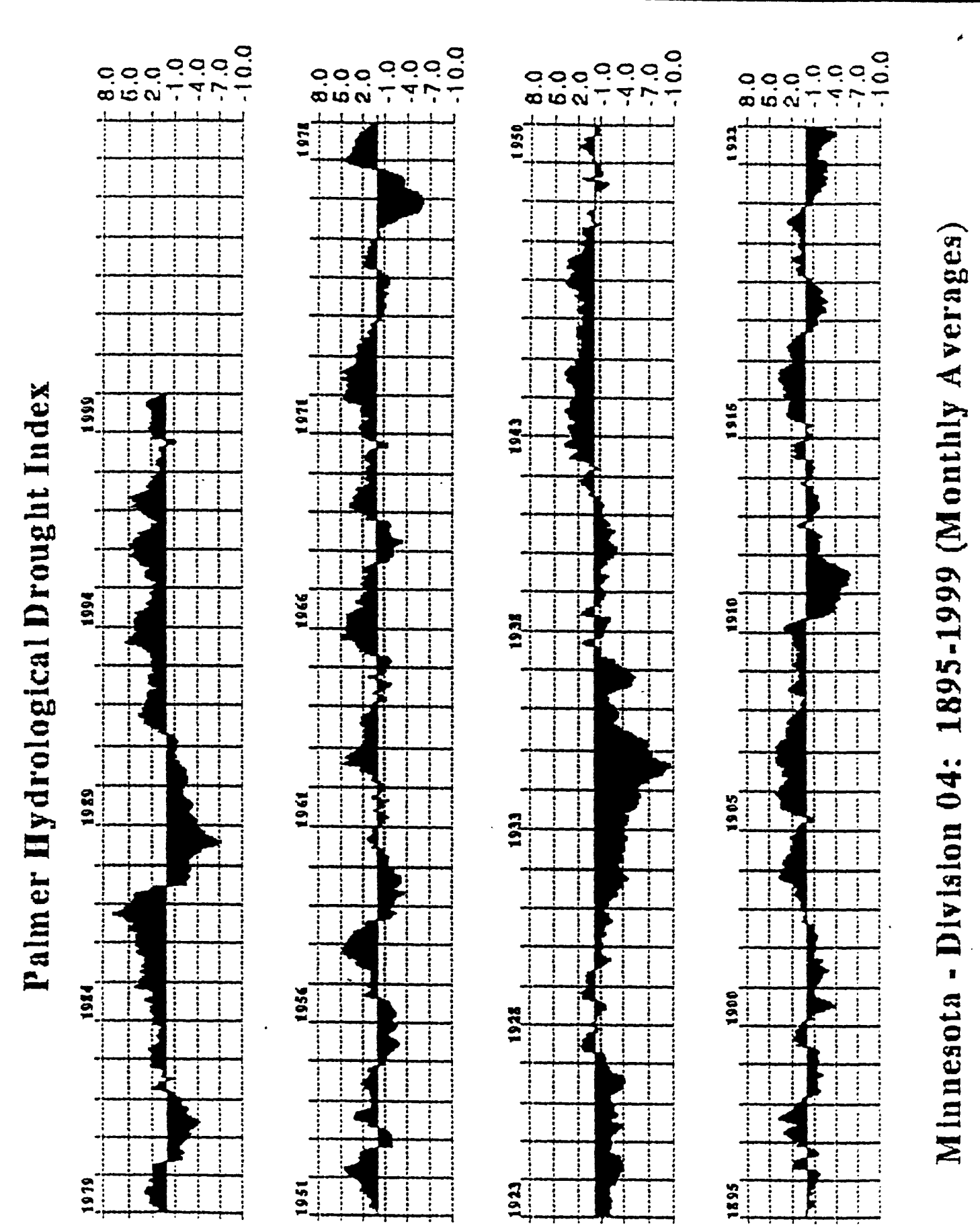

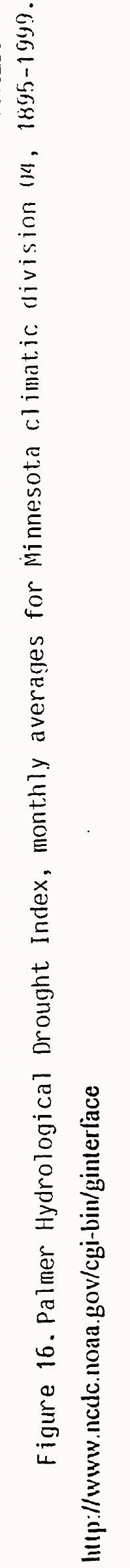


Although not reviewed, a new tool that monitors drought indices nationally is accessible via the Internet. This tool will be one of the tools used to give early warning of drought conditions and drought formation in North Dakota, and it will supplement locally produced drought information. This new tool is called the U.S. Drought Monitor (supp. 14). The U.S. Drought Monitor is a synthesis of multiple indices, outlooks, and newspaper accounts that represent a consensus of Federal and academic scientists. The U.S. Drought Monitor provides a weekly overview of where drought is emerging, lingering, subsiding, or forecast. This tool can be used along with products produced by the National Weather Service Forecast Offices to help determine the probability of drought streamflow. The U.S. Drought Monitor is produced jointly by the National Weather Service's Climate Prediction Center, the U.S. Department of Agriculture, and the National Drought Mitigation Center at the University of Nebraska-Lincoln.

\section{Drought Indices Annual Review and Report}

A drought indices annual review is part of the 9-month time line of events preceding the study. The purpose of the annual review is to determine if drought streamflow could occur during the following field season and to keep the work plan current. For example, during annual review, the mobilization captain's name and telephone number (supp. 15) and the instrument contact person's name and telephone number would be verified. The annual review should be ongoing and annually funded. Annual funding will ensure the study's viability from year to year regardless of personnel changes in the U.S. Geological Survey or cooperator offices. The required funding will cover annual costs to renew the contract and prepare a 1- to 2-page annual report for the cooperators.

To prepare the annual review, the following information sources would be used:

1. National drought monitoring and watches

a. U.S. Drought monitor - http://enso.unl.edu/monitor/monitor.html

b. High Plains Climate Center - http://www.hpccsun.unl.edu/

c. Multiple drought-information sources at - http://www.ccsp.sfu.ca/hazard/RECENT/drought.html

2. Local drought-monitoring indices. Current North Dakota climatic conditions are available from http:enso.unl.edu/monitor/current.html for the following categories:
a. Standardized precipitation index
b. Percentage of normal rainfall
c. Daily streamflow map
d. Snowpack
e. Soil moisture
f. Daily soil-moisture anomaly

3. Additional drought-monitoring sources
a. USGS National Home Page - http://water.usgs.gov
b. USGS Drought Watch ' 99 - http://md.usgs.gov/drought/mid_atl.gtml

4. North Dakota real-time indicator of streamflow conditions

a. Tracking current streamflow with historic streamflow and examining its current trend can be done using the U.S. Geological Survey North Dakota District's computer and software. By using the nwts2rdb command (command is executed from a window when user is attached to the sn01 server), current daily means are extracted in rdb format. Then, historic daily minimum, mean, and maximum data can be retrieved in rdb format by using the program DVDAYSTAT. The data can then be plotted using the G2 program. 
A 9-month time line of events that precede the study (supp. 16) starts each October with a review of the drought indices and annual report. The following is a proposed outline of the annual report contents:

National drought-monitoring summary

U.S. Drought monitor

High Plains Climate Center

Additional sources

Local drought-monitoring summary

Standardized precipitation index

Percentage of normal rainfall

Daily streamflow map

Snowpack

Soil moisture

Daily soil-moisture anomaly

Real-time indicator of streamflow conditions

Compare current daily mean streamflow with historic daily streamfiow for minimum, mean, and maximum for Red River of the North at Fargo, N. Dak., gaging station (05054000)

Conclusion

What is the likelihood of climatic conditions producing drought streamflows in the Red River near Fargo and Moorhead. 


\section{REFERENCES}

Jobson, H.E., and Schoellhamer, D.H., 1987, Users manual for a branched Lagrangian transport model: U.S. Geological Survey Water-Resources Investigations Report 87-4163, 80 p.

Jobson, H.E., 1989, Users manual for an open-channel streamflow model based on the diffusion analogy: U.S. Geological Survey Water-Resources Investigations Report 89-4133, $73 \mathrm{p}$.

Kilpatrick, F.A., Rathbun, R.E., Yotsukura, N., Parker, G.W., and DeLong, L.L., 1989, Determination of stream reaeration coefficients by use of tracers: U.S. Geological Survey Techniques of Water-Resources Investigations, book 3, Chap. A18, 52 p.

Kilpatrick, F.A., and Wilson, J.F., Jr., 1989, Measurement of time of travel in streams by dye tracing: U.S. Geological Survey Techniques of Water-Resources Investigations, book 3, Chap. A9, 27 p.

Murphy, P.J., and Hicks, D.B., 1986, In-situ method for measuring sediment oxygen demand, in Hatcher, K.J., ed., Sediment oxygen demand--Processes, modeling, and measurements: 56th Annual Conference of the Water Pollution Control Federation, Athens, Georgia, University of Georgia, October 2-7, 1983, p. 307-322.

Shelton, L.R., 1994, Field guide for collecting and processing stream-water samples for the National Water-Quality Assessment program: U.S. Geological Survey Open-File Report 94-455, p. 42.

Smoot, J.L., 1987, Effect of streamflow conditions on gas-transfer coefficients: Proceedings of the 1987 National Conference on Hydraulic Engineering, Hydraulic Division, American Society of Civil Engineers, August 3-7, 1987, p. 980-985.

U.S. Environmental Protection Agency, Office of Water, Assessment and Watershed Protection Division, 1991, Guidance for water quality-based decisions--The TMDL Process: EPA 440/4-91-001, April 1991, 58 p.

Wesolowski, E.A., 1994, Calibration, verification, and use of a water-quality model to simulate effects of discharging treated wastewater to the Red River of the North at Fargo, North Dakota: U.S. Geological Survey Water-Resources Investigations Report $94-4058,143 \mathrm{p}$.

Wesolowski, E.A., 1996a, Simulation of wastewater effects on dissolved oxygen during low streamflow in the Red River of the North at Fargo, North Dakota, and Moorhead, Minnesota: U.S. Geological Survey Fact Sheet FS-235-96, 4 p.

Wesolowski, E.A., 1996b, Uncertainty analysis of the simulations of effects of discharging treated wastewater to the Red River of the North at Fargo, North Dakota, and Moorhead, Minnesota: U.S. Geological Survey Water-Resources Investigations Report 96-4015, $27 \mathrm{p}$.

Wiche, G.J., and Williams-Sether, Tara, 1997, Streamflow characteristics of streams in the upper Red River of the North Basin, North Dakota, Minnesota, and South Đakota: U.S. Geological Survey Open-File Report 97-416, 374 p. 


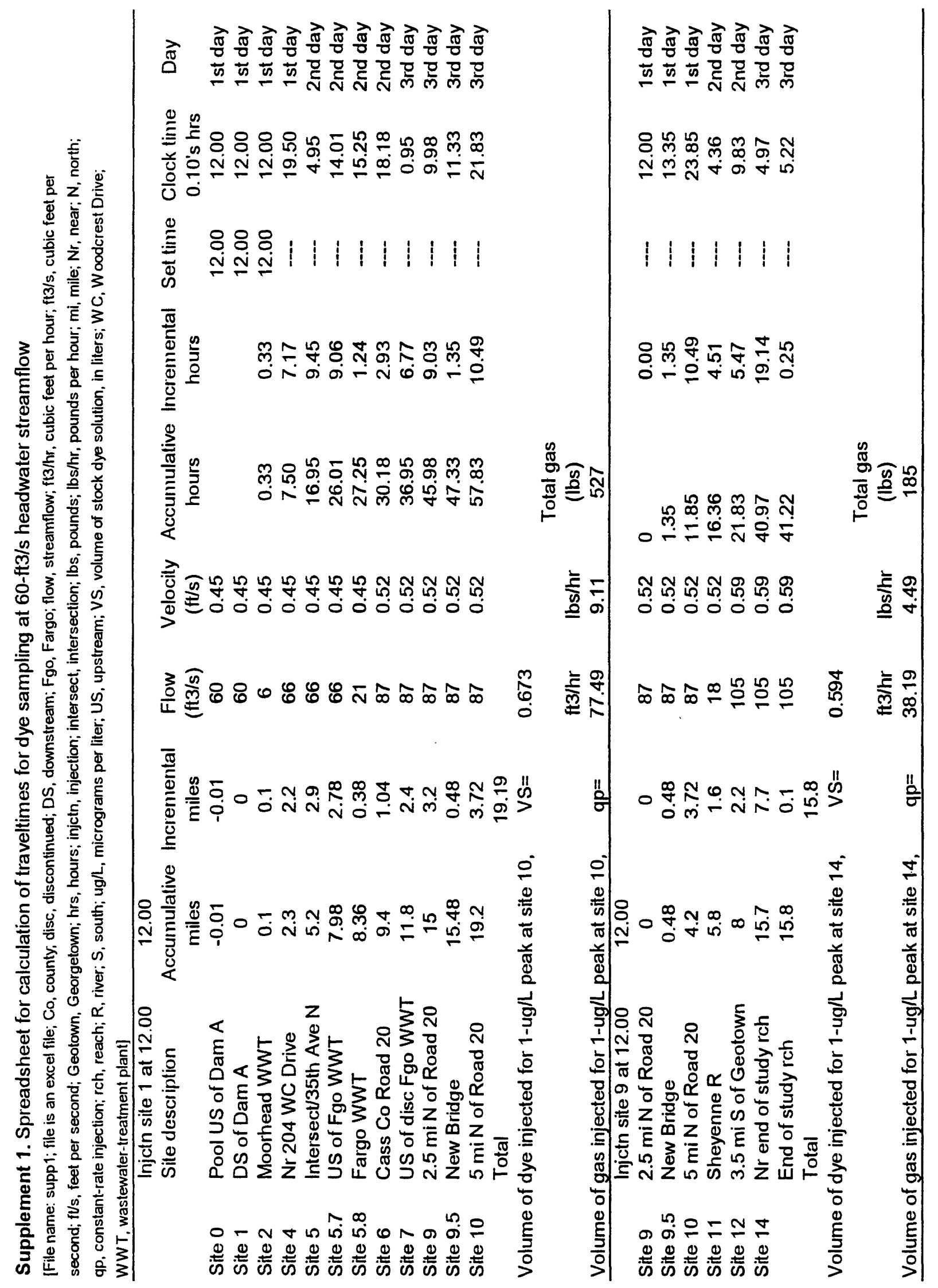



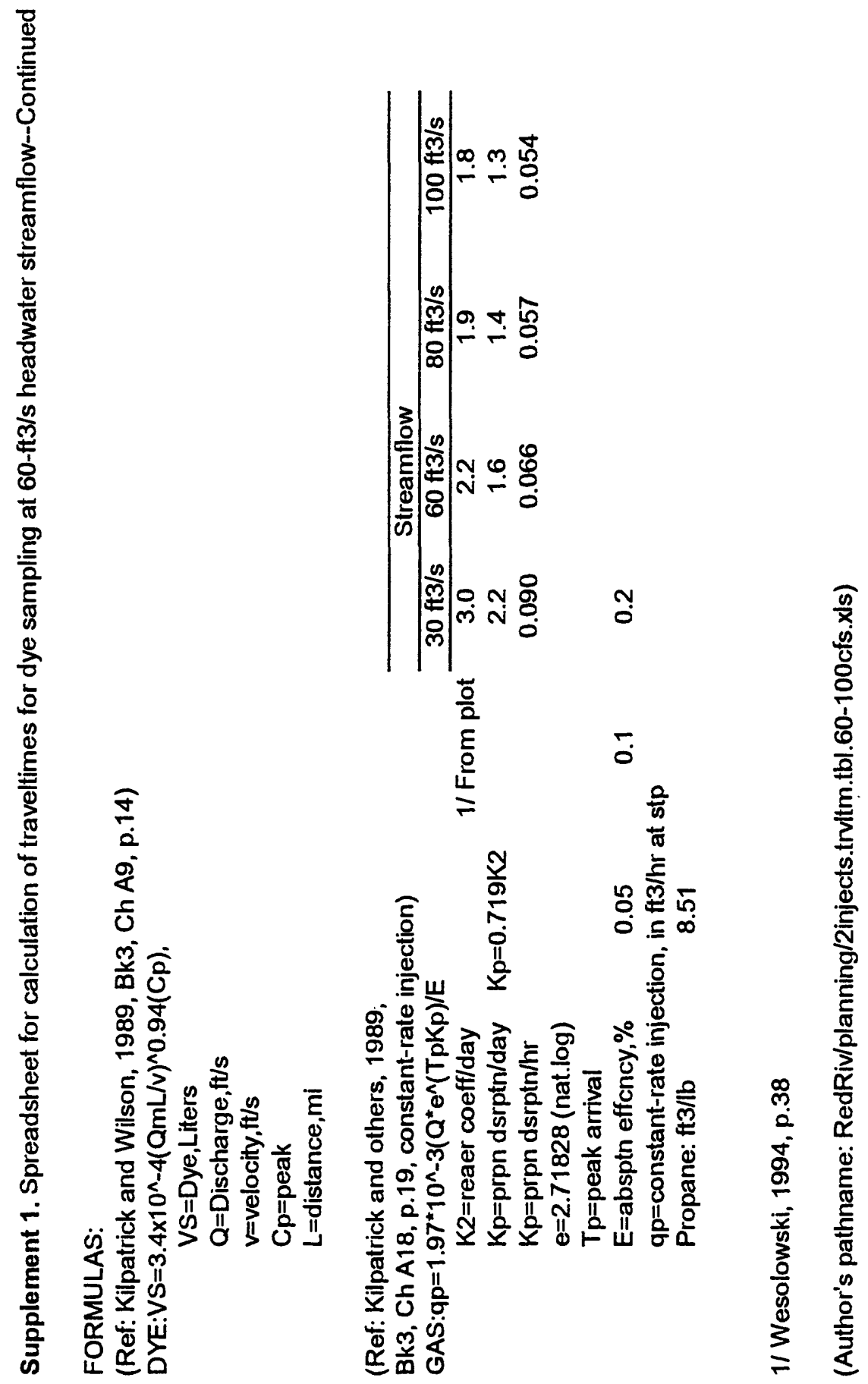


\section{Supplement 2. Tracer-sampling instructions}

[File name: supp2; file is a word file]

\section{DYE-SAMPLE COLLECTION PROCEDURE:}

1. Before collecting a sample, rinse bottles with river water.

2. Collect sample at streamflow line marked by steel fencepost.

3. Two samples are collected simultaneously using two glass bottles held in place by a heavy-duty rubberband on a short, angle-iron sampler or on a gas, air-displacement sampler--see gas-sample collection procedure.

4. Collect enough samples to define entire dye cloud (usually 30 well-placed data points). Try to collect sample at peak concentration. In general, one-third of the samples will define the rising limb of the dye-concentration curve and two-thirds will define the remainder. Depending on the expected shape of the dye cloud, sampling intervals can vary from 2 minutes on the rising limb to 1 to 2 hours on the falling limb of the curve.

5. One dye sample is analyzed immediately after collection using a field-calibrated fluorometer. The second dye sample is capped, labeled with river name, site number, time (military), and date and stored in boxes ( 5 inches by 5 inches by 5 inches) for reanalysis. The second sample will be reanalyzed in the laboratory at a later date when all the dye samples are being reanalyzed by the same laboratory-calibrated fluorometer under temperaturecontrolled conditions.

6. Record "appropriate data" on field sheet. (See tracer sampling field-sample note sheet; supp. 7).

7. Samples are collected at intervals appropriate to define the entire dye cloud, especially during the peak.

8. Dye samples are collected until the dye concentration recedes to 2 percent of the peak dye concentration or 0.1 microgram per liter, whichever is larger.

\section{GAS-SAMPLE COLLECTION PROCEDURE (BASED ON CONSTANT-RATE INJECTION):}

1. Use two small air-displacement-type samplers. Place the glass sample vial inside of the sampler. Samples are collected simultaneously in duplicate. Both samples are sent to the laboratory.

2. Collect samples at the same collection point where the dye sample is collected.

3. Begin sample collection after the dye concentration reaches 2 percent of the peak or 0.1 microgram per liter, whichever is larger. Collect seven samples in 30-minute intervals. Gas samples are collected at one-half the frequency the dye samples are collected. However, sample at the peak gas concentration, which should coincide with the peak dye concentration.

4. Remove vial from sampler.

5. Inject 1 milliliter of formalin solution into the sample using the automatic pipette.

6. Make sure the vial is overfilled so that the water is slightly rounded above the mouth.

7. Carefully slide the septum across the top of the vial so that no air bubbles are produced. The white side of the septum should contact the sample.

8. Hold the septum in place and carefully affix the screw cap. Tighten the cap. 
Supplement 2. Tracer-sampling instructions--Continued

9. Invert the sealed vial to check for air bubbles. If there are any, the sample should be rebottled because the presence of bubbles will affect the analysis. Rebottling is accomplished by removing the cap and septum, carefully pouring some of the sample water remaining in the sampler to "mound up" the sample, then resliding the septum across the top of the vial and cap.

10. Affix a label to the vial with river name, site number, time (military), and date on the label. Store in boxes ( 5 inches by 5 inches by 5 inches).

11. All samples will be mailed together to the U.S. Geological Survey Central Laboratory in Ocala, Fla., at a later date.

(Author's pathname: red.low.flow/study.plan/lists.forms/tracer.sampling.instructions.txt) 
Supplement 3. Supplies and equipment needed by the tracer-injection crew

[File name: supp3; file is a word file; needs to be updated from slug injection to constant-rate injection]

\begin{tabular}{|c|c|}
\hline Amount & Item \\
\hline & Dye \\
\hline 1 & Cell phone \\
\hline 5 & Dye (20-percent), prepackaged in 450-milliliter containers \\
\hline 1 & Dye-metering pump \\
\hline 1 & 12-volt, dry-cell battery and spare \\
\hline 1 & Large graduated cylinder for dispensing dye \\
\hline \multirow[t]{2}{*}{50 feet } & Tubing \\
\hline & Connectors: male, female, and nipples \\
\hline 1 roll & Black tape \\
\hline 9 & Steel fenceposts; eight to mark 50-percent streamflow line and one to support dye-injection tubing \\
\hline 1 & Post driver \\
\hline 1 & Clipboard \\
\hline 1 per injection site & Forms to record volume of dye injected \\
\hline 1 pair & Plastic gloves \\
\hline 1 & Bathroom scale to measure gas consumption \\
\hline 1 box & Tissue \\
\hline \multicolumn{2}{|r|}{ Propane } \\
\hline 3 & Diffusers (with supports?) \\
\hline 2 & Gas cylinders, 20 pounds net ( 40 pounds gross) \\
\hline 1 & Regulator with flow meter \\
\hline 1 & Regulator, spare \\
\hline 1 & Spare flow meter, free standing \\
\hline I box & Tools \\
\hline
\end{tabular}

(Authors's pathname: red.low.flow/study.plan/lists.forms/supplies.equipe.for.injection.txt) 
Supplement 4. Supplies and equipment needed by the tracer-sampling crew

[File name: supp4; file is a word file; needs to be updated for the Red River drought streamflow study]

\begin{tabular}{|c|c|}
\hline Amount & Item \\
\hline 1 each & $\begin{array}{l}\text { Instruction packet containing: } \\
\text { Set of topographic maps with site locations } \\
\text { Itinerary for traveltime } \\
\text { Tracer-sampling procedure (supp. 2) } \\
\text { Fluorometer operation procedure }\end{array}$ \\
\hline 1 & Cell phone \\
\hline 1 & Fluorometer with 12-volt battery and a spare (battery chargers will be available at water-treatment plant) \\
\hline 3 & Cuvertes (team using North Dakota fluorometer only) \\
\hline 2 boxes & Tissue paper \\
\hline 1 set & Dye standards \\
\hline 2 sets & Extra fuses for fluorometer: 2 ampere and $1 / 2$ ampere \\
\hline 7 & Boxes ( 5 inches by 5 inches by 5 inches) to store dye samples ( 25 bottles per box) \\
\hline 20 & Field-sample note sheet for dye and gas \\
\hline 1 & Clipboard \\
\hline 150 & Dye bottles and caps \\
\hline 75 & Gas bottles with caps and septum \\
\hline 1 & Dye sampler (angle-iron) with rope \\
\hline 225 & Labels \\
\hline 2 & Gas sampler (air-displacement type) with chain/rope \\
\hline 125 milliliters & Gas-sample preservative (formalin) \\
\hline 1 & Auto pipette set to 1 milliliter \\
\hline 1 & Thermometer \\
\hline 2 & Flashlights \\
\hline 2 & Lanterns \\
\hline 1 each & Hip boots and waders \\
\hline-- & Supply of distilled or demineralized water \\
\hline
\end{tabular}

(Author's pathname: red.low.flow/study.plan/lists.forms/supply.inventory.tracer.txt) 


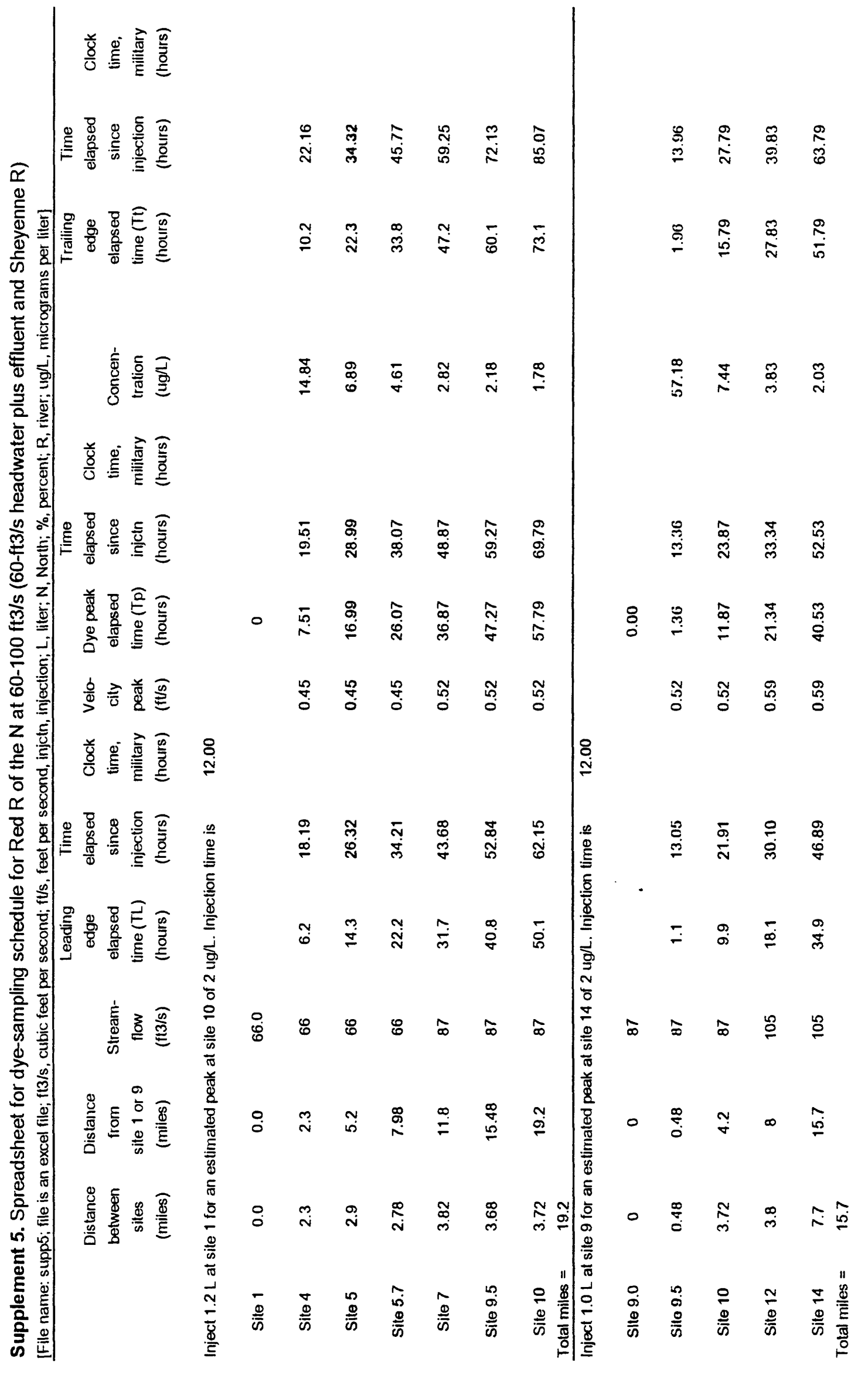




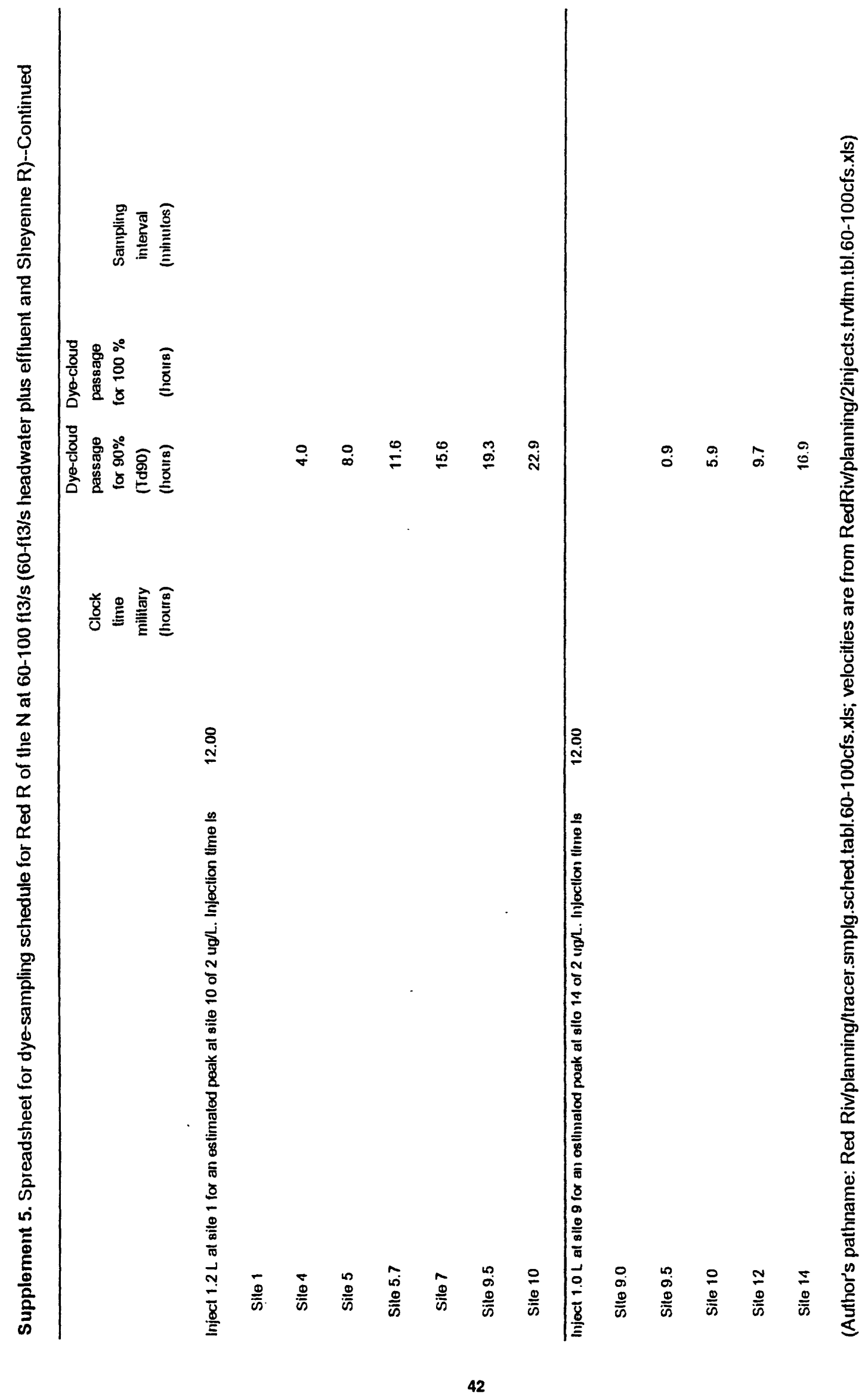




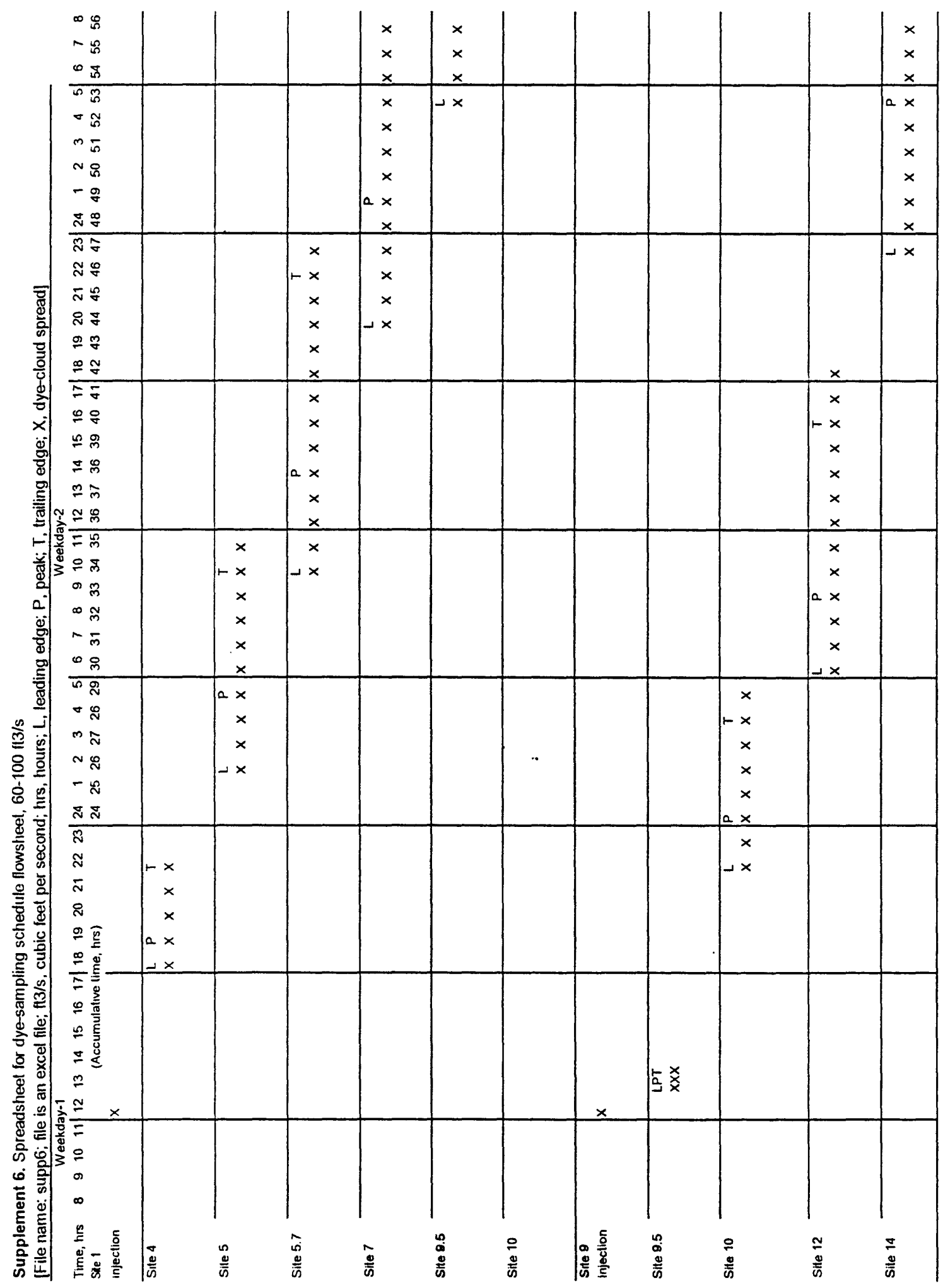




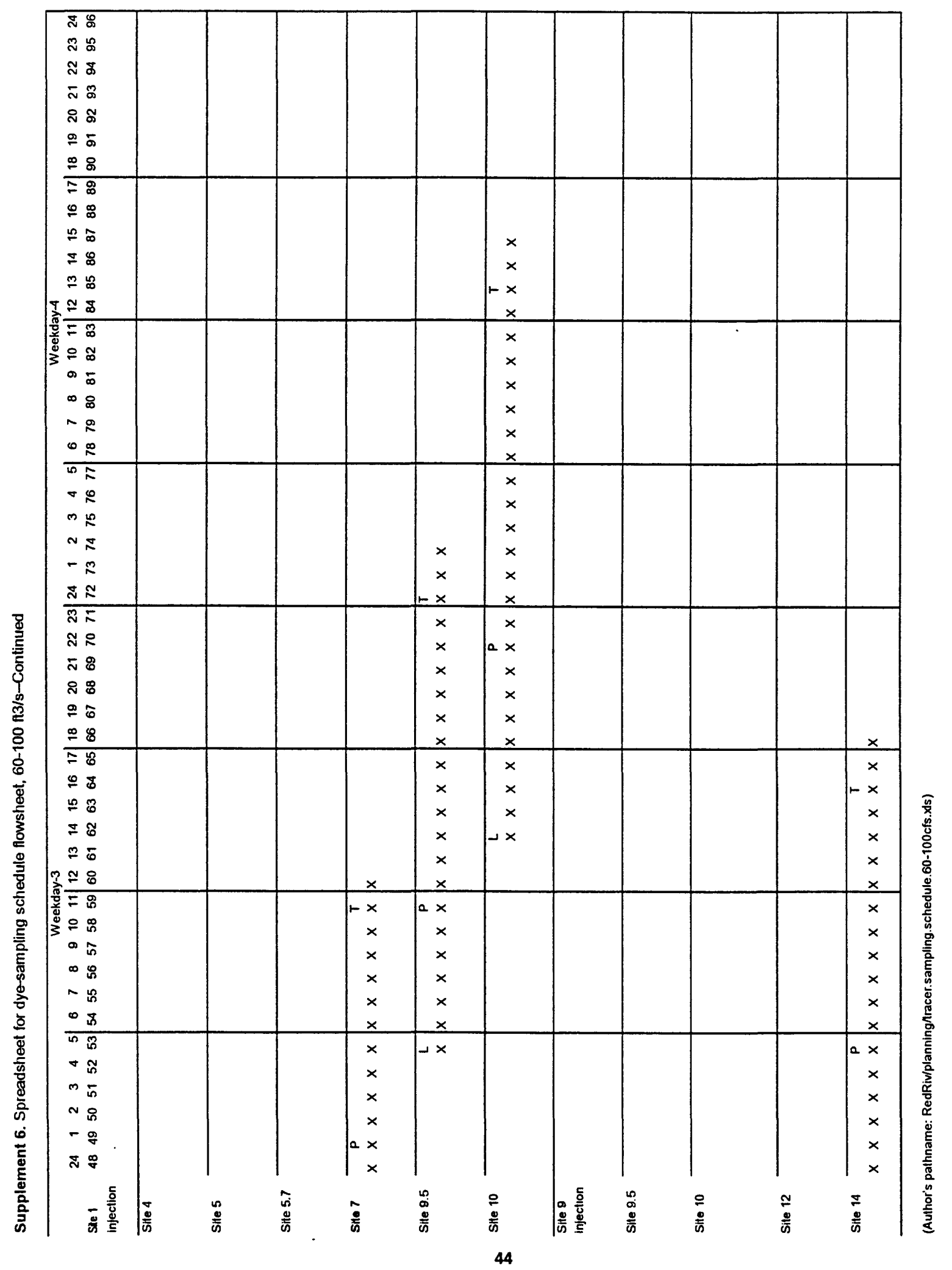


Supplement 7. Tracer sampling field-sample note sheet

[File name: supp7; file is a word file]

LOCATION:

DATE:

NAME:

FLUOROMETER \# (circle appropriate one) (ND:W-375558) (MO:W-412536) (FL:W-488014)

\begin{tabular}{|c|c|c|c|c|c|c|c|c|}
\hline \multirow[b]{3}{*}{ Time } & \multirow[b]{3}{*}{$\begin{array}{c}\text { Cross-section } \# \\
\text { right }=1, \\
\text { center }=2, \\
\text { left }=3\end{array}$} & \multicolumn{5}{|c|}{ Dye samples } & \multirow{2}{*}{\multicolumn{2}{|c|}{$\begin{array}{c}\text { Gas samples } \\
\text { Laboratory } \\
\text { sample collected }\end{array}$}} \\
\hline & & \multicolumn{3}{|c|}{ Fluorometer } & \multicolumn{2}{|c|}{$\begin{array}{c}\text { Laboratory } \\
\text { sample collected }\end{array}$} & & \\
\hline & & $\begin{array}{l}\text { Scale } \\
\text { multiplier } \\
\text { X1 or } \\
\text { X100 }\end{array}$ & $\begin{array}{c}\text { Light \# } \\
1,2,3 \text {, or } 4\end{array}$ & $\begin{array}{l}\text { Field } \\
\text { reading }\end{array}$ & $\begin{array}{c}\text { Yes } \\
\text { or } \\
\text { no }\end{array}$ & Value & $\begin{array}{c}\text { Yes } \\
\text { or } \\
\text { no }\end{array}$ & Value \\
\hline & & & & & & & & \\
\hline & & & & & & & & \\
\hline & & & & & & & & \\
\hline & & & & & & & & \\
\hline & & & & & & & & \\
\hline & & & & & & & & \\
\hline & & & & & & & & \\
\hline & & & & & & & & \\
\hline & & & & & & & & \\
\hline & & & & & & & & \\
\hline & & & & & & & & \\
\hline & & & & & & & & \\
\hline & & & & & & & & \\
\hline & & & & & & & & \\
\hline & & & & & & & & \\
\hline & & & & & & & & \\
\hline
\end{tabular}

(Author's pathname: red.low.flow/study.plan/lists.forms/dye.field.sheet.fm) 


\begin{tabular}{|c|c|c|c|c|c|}
\hline \multicolumn{6}{|c|}{$\begin{array}{l}\text { Supplement 8. Sediment-oxygen-demand measurement sheet } \\
\text { [File name: supp8; file is a word file; } \mathrm{mg} / \mathrm{L} \text {, milligrams per liter] }\end{array}$} \\
\hline & Site number & Date & \multicolumn{3}{|c|}{ Site number } \\
\hline & \multicolumn{5}{|c|}{ Beginning meter readings } \\
\hline & Instream & $\begin{array}{l}\text { Nonrecording } \\
\text { meter } \# 1\end{array}$ & $\begin{array}{l}\text { Nonrecording } \\
\text { meter \# } 2\end{array}$ & $\begin{array}{l}\text { Recording } \\
\text { meter \# } 3\end{array}$ & $\begin{array}{l}\text { Recording } \\
\text { meter \# } 4\end{array}$ \\
\hline \multicolumn{6}{|l|}{ Meter, volts } \\
\hline \multicolumn{6}{|l|}{ Battery, volts } \\
\hline \multicolumn{6}{|l|}{ Water temp. } \\
\hline & & \multicolumn{4}{|c|}{ SEDIMENT-OXYGEN-DEMAND VALUES (mg/L) } \\
\hline Time & $\begin{array}{l}\text { Instream } \\
\text { oxygen }\end{array}$ & $\begin{array}{l}\begin{array}{l}\text { Control } \\
\text { chamber \# } 1\end{array} \\
\end{array}$ & $\begin{array}{l}\begin{array}{l}\text { Benthic } \\
\text { chamber \# } 2\end{array} \\
\end{array}$ & $\begin{array}{l}\begin{array}{l}\text { Benthic } \\
\text { chamber \# } 3\end{array} \\
\end{array}$ & \begin{tabular}{|l}
$\begin{array}{l}\text { Benthic } \\
\text { chamber \# } 4\end{array}$ \\
\end{tabular} \\
\hline & & & & & \\
\hline & & & & & \\
\hline & & & & & \\
\hline & & & & & \\
\hline & & & & & \\
\hline & & & & & \\
\hline & & & & & \\
\hline & & & & & \\
\hline & & & & & \\
\hline & & & & & \\
\hline & & & & & \\
\hline & & & & & \\
\hline & & & & & \\
\hline & & & & & \\
\hline & & & & & \\
\hline & & & & & \\
\hline & & & & & \\
\hline & & & & & \\
\hline & & & & & \\
\hline & & & & & \\
\hline & & & & & \\
\hline & & & & & \\
\hline & & & & & \\
\hline & & & & & \\
\hline & & & & & \\
\hline & & & & & \\
\hline & & & & & \\
\hline & & & & & \\
\hline & & & & & \\
\hline & & & Ending meter read & & \\
\hline Meter, volts & & & & & \\
\hline Battery, volts & & & & & \\
\hline Water temp. & & & & & \\
\hline
\end{tabular}

(Author's pathname: RedRiviplanning/field.table.sod.doc) 
Supplement 9. Respirometer dissolved-oxygen note sheet for use with Yellow Springs dissolved-oxygen recorder [File name: supp9; file is a word file]

Station name/number

Date collected

Meter $\mathrm{O}_{2}$ range Meter number

Time collected

Chart speed

Water volume

Resp. number

Starting calibration:

Pen temperature (nonchamber)

Thermometer temperature

Barometeric pressure

Pen temperature (chamber)

Corrected chamber temp.

D.O. calibration value

Time started

Ending calibration:

Ending time

Pen temperature (nonchamber)

Barometeric pressure

Pen temperature (chamber)

Corrected chamber temp.

D.O. calibration value

D.O. meter reading

Comments/remarks

(Author's pathname: RedRiv/planning/respirometer.DO.sheet) 
Supplement 10. Supplies and equipment needed for sediment-oxygen-demand measurements

[File name: supp 10; file is a word file; needs to be updated for the Red River drought streamflow study]

\begin{tabular}{|c|c|}
\hline Amount & Item \\
\hline 1 & Cell phone \\
\hline 4 & Sediment-oxygen-demand chambers; one with sealed bottom with water circulation motor that draws 1.0 ampere \\
\hline 2 & Spare motors for chambers \\
\hline Assorted & Solderless connectors \\
\hline 1 roll each & Tape, electrician and duct \\
\hline 1 & Toolbox \\
\hline Assorted & Tubing for sediment-oxygen-demand chambers \\
\hline 4 & Wet-cell batteries-or eight dry-cell batteries \\
\hline 1 tube & Silicone with dispenser \\
\hline 1 & Steel fencepost \\
\hline 1 & Fencepost driver \\
\hline 1 & Voltage meter \\
\hline 7 & $\begin{array}{l}\text { Dissolved-oxygen meters--two recording, with stirrers for use in chamber; two nonrecording, with stirrers for use in } \\
\text { chamber; three nonrecording, with stirrers-one for use in stream and two as backup meters }\end{array}$ \\
\hline 2 & Probes, spares \\
\hline- & Dissolved-oxygen-meter supplies, membranes, etc. \\
\hline 1 & Inverter for self-stirring biochemical-oxygen-demand probe \\
\hline 1 & Self-stirring biochemical-oxygen-demand probe \\
\hline 3 & Biochemical-oxygen-demand bottles (one light, two dark) \\
\hline 1 & Dissolved-oxygen sampler (also known as sewage sampler) \\
\hline 1 & Water jug \\
\hline 1 & Wet suit with water shoes \\
\hline 1 & Chest waders and hip boots \\
\hline 1 & Camera \\
\hline 1 & Calibration chamber (wand) for dissolved-oxygen probes \\
\hline 1 & Barometer \\
\hline 1 & Dissolved-oxygen saturation table \\
\hline 1 roll & Paper towels \\
\hline-- & Various-sized rubber stoppers used to evacuate air from the chamber \\
\hline
\end{tabular}

(Author's pathname: RedRiviplanning/sod.supplies.equip.doc) 


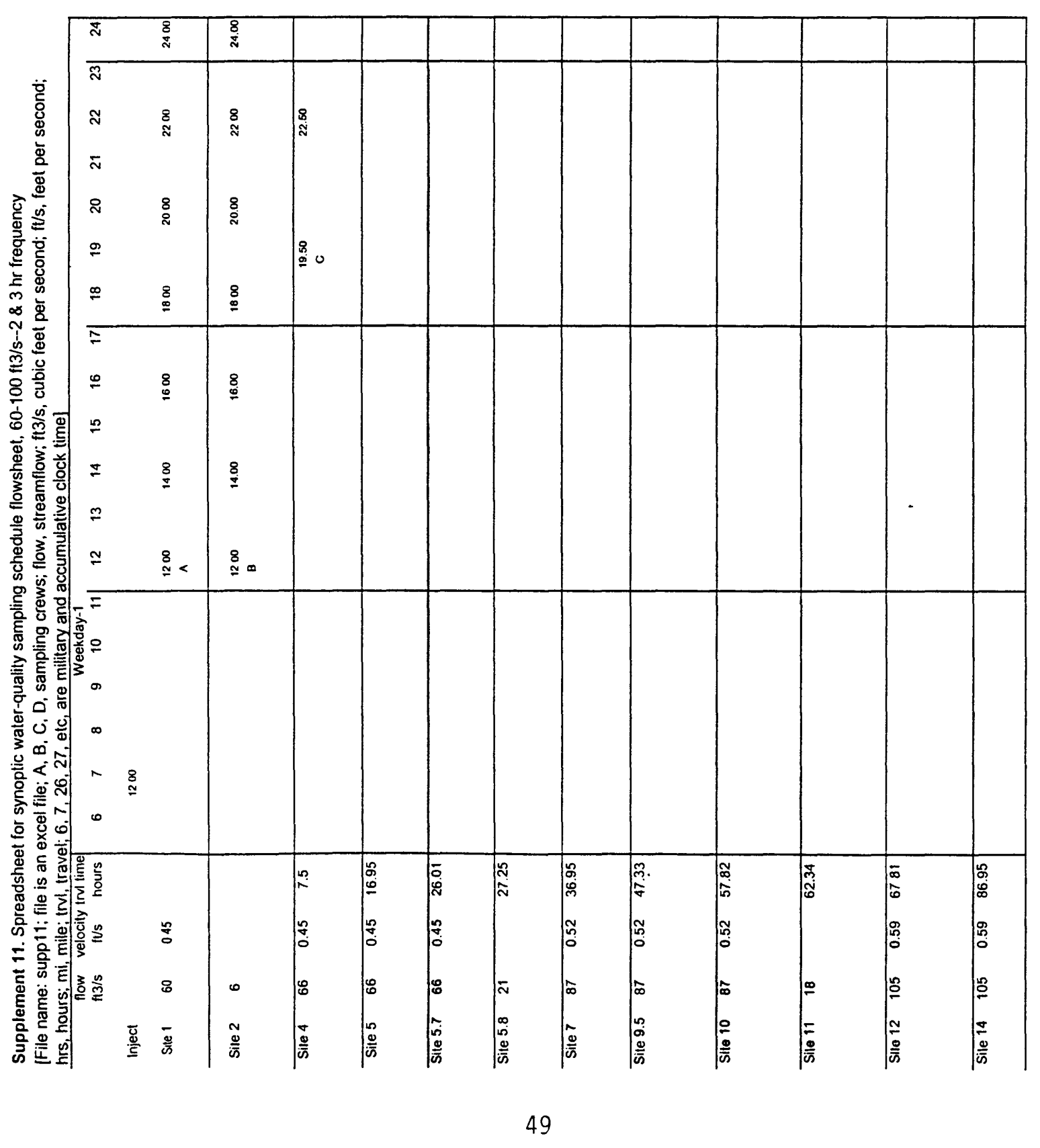




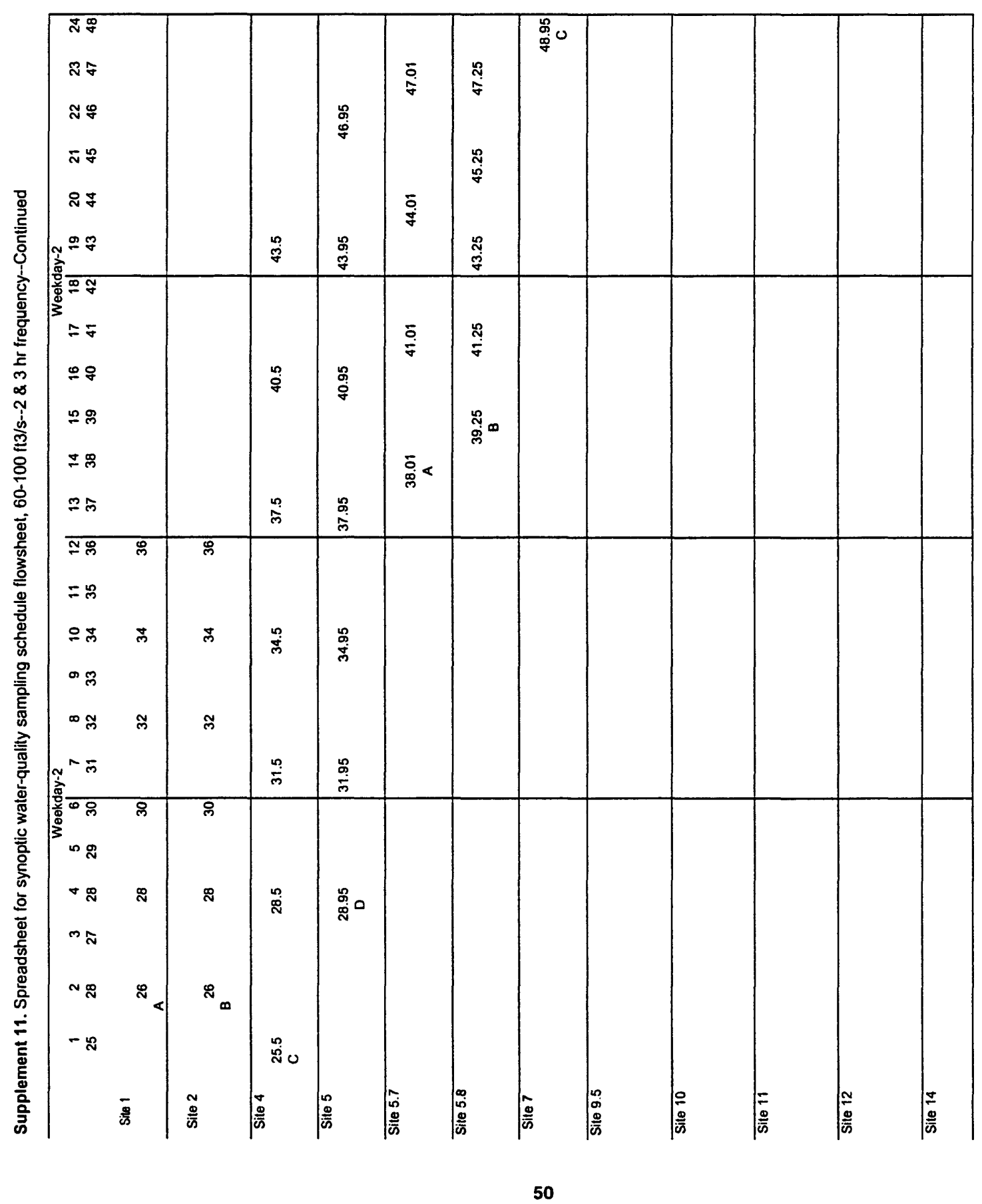




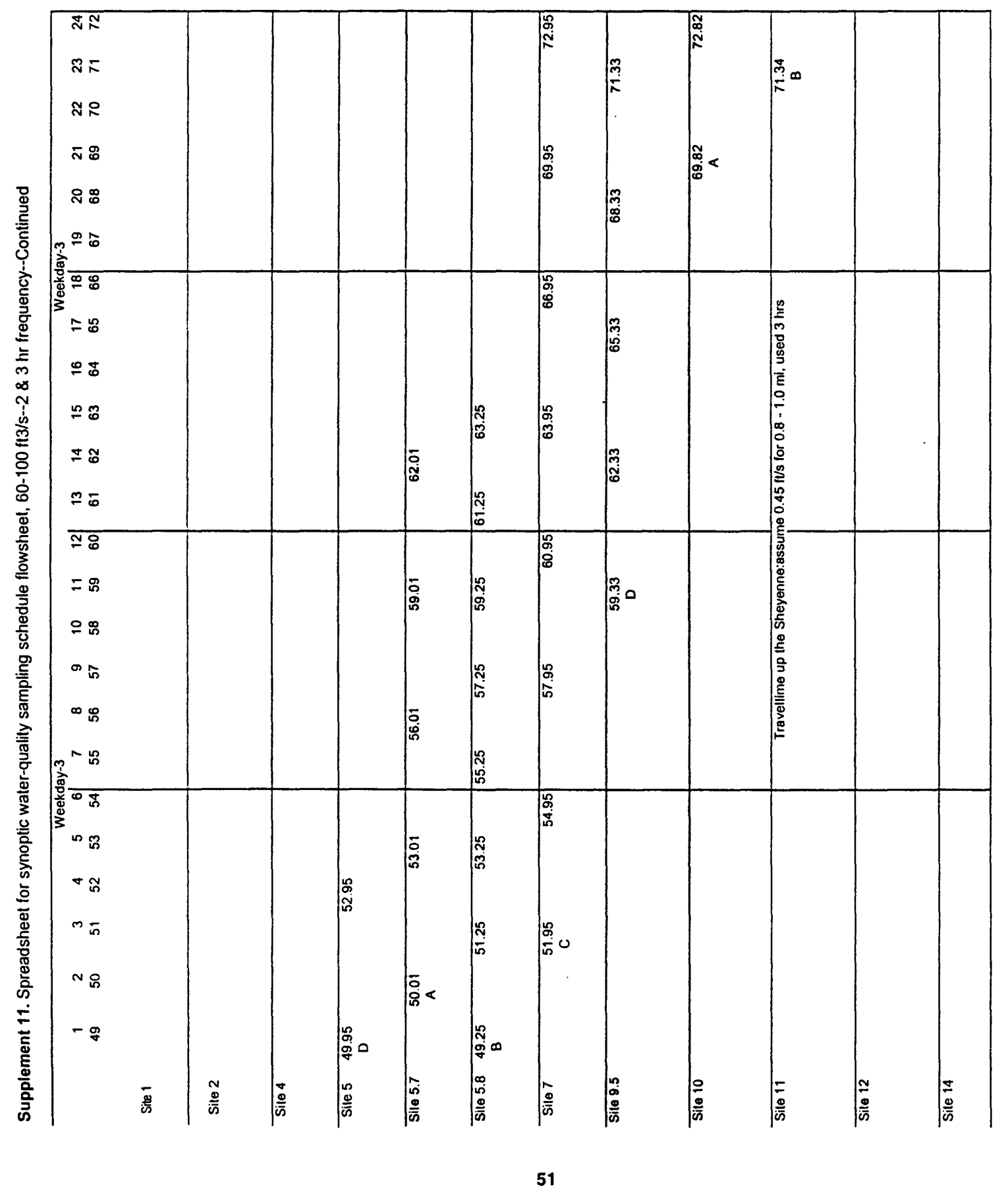









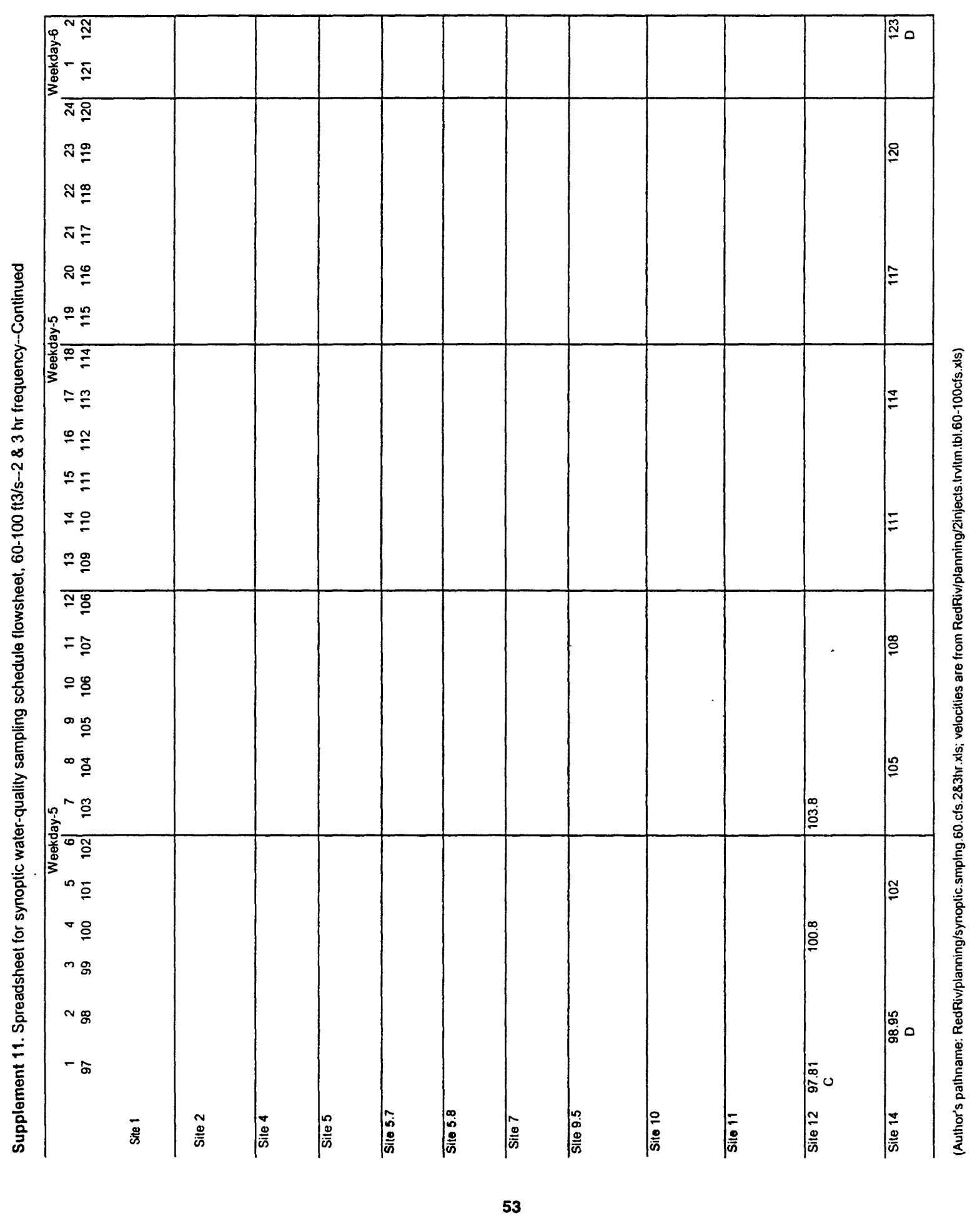


Supplement 12. Multiparameter water-quality instrument (Hydrolab or similar) calibration sheet [File name: supp 12; file is a word file]

Instrument Serial no.

Party

\begin{tabular}{|c|c|c|c|c|c|c|}
\hline Date & Time & & $\begin{array}{c}\text { Water } \\
\text { temperature } \\
(00010)\end{array}$ & $\begin{array}{c}\text { Specific } \\
\text { conductance } \\
(00095)\end{array}$ & $\begin{array}{c}\mathrm{pH} \\
(00400)\end{array}$ & $\begin{array}{c}\text { Dissolved } \\
\text { oxygen } \\
(00300) \\
\end{array}$ \\
\hline & & $\overline{\text { Standard }}$ & & & & \\
\hline & & Reads & & & & \\
\hline & & Reset?To? & & & & \\
\hline & & & & & & \\
\hline & & Standard & & & & \\
\hline & & Reads & & & & \\
\hline & & Reset?To? & & & & \\
\hline & & & & & & \\
\hline & & Standard & & & & \\
\hline & & Reads & & & & \\
\hline & & Reset?To? & & & & \\
\hline & & & & & & \\
\hline & & Standard & & & & \\
\hline & & Reads & & & & \\
\hline & & Reset?To? & & & & \\
\hline & & & & & & \\
\hline & & & & & & \\
\hline & & & & & & \\
\hline
\end{tabular}

(Author's pathname: red.low.flow/study.plan/lists.forms/hydrolab.calib.sheet) 
Supplement 13. Supplies and equipment needed by each of four synoptic-sampling crews

[File name: supp 13; file is a word file; needs to be updated for the Red River drought streamflow study]

\begin{tabular}{|c|c|}
\hline Amount & Item \\
\hline 1 & Trip folder; includes this inventory list, maps with sampling sites, and labels \\
\hline 1 & Cellular phone \\
\hline-- & Rope \\
\hline 1 & Spade/shovel \\
\hline 1 & Lantern (2-mantel) plus fuel and extra mantels \\
\hline 2 & Flotation jackets \\
\hline 1 & Sediment sampler (DH48 and spare nozzle); use 5/16-inch nozzle \\
\hline 1 & Dissolved-oxygen "sewage" sampler to collect 300-milliliter sample for Wrinkler test measurement \\
\hline 1 & Weighted bottle sampler (about 2-liter size) \\
\hline 1 & Churn splitter \\
\hline 25 (needs updating) & 250-milliliter bottle (round), nitrite plus biomass (dry and ash weight) with labels (provided) \\
\hline 25 (needs updating) & 500 -milliliter bottle (square); total $\mathrm{P}$, ammonia, TKN, NO3+NO2 with labels (provided) \\
\hline 36 each & Ziplock plastic bags ( 9 inches by 9 inches) for U.S. Geological Survey Analytical Services request forms \\
\hline 50 (needs updating) & U.S. Geological Survey Analytical Services request form and water-quality field notes form \\
\hline 72 & 1-gallon cubitainers for biochemical-oxygen-demand samples \\
\hline 1 & Permanent marker for labeling \\
\hline 36 & Borosilicate filters (47-millimeter) for phytoplankton algae (chlorophyll a) \\
\hline 36 & Petri dishes to place borosilicate filters for algae chlorophyll a \\
\hline 1 & Forceps to handle borosilicate filter \\
\hline 1 & Millipore-filter apparatus for borosilicate filters for chlorophyll a \\
\hline 1 roll & Electrician's tape for petri dishes containing borosilicate filter \\
\hline 1 & Hydrolab (primary instrument; calibrate before and after sampling with appropriate calibration standards) \\
\hline 1 & Portable barometer \\
\hline 1 & Hach-kit digital titrator with prepackaged chemicals \\
\hline 1 & Hach-kit digital titrator with prepackaged chemicals to measure alkalinity \\
\hline 1 & $\mathrm{pH}$ meter (backup) \\
\hline 1 & Specific-conductance meter (backup) \\
\hline 1 & Dissolved-oxygen meter (backup) \\
\hline 1 & Thermometer (backup) \\
\hline 2 & Graduated cylinders, 100-milliliter \\
\hline 1 & Flashlight, 6-volt \\
\hline 1 & Fluorometer with a supply of dye bottles and a sampler \\
\hline- & Enough coolers or refrigerators to chill and hold samples for one 12-hour shift \\
\hline
\end{tabular}

(Author's pathname: red.low.flow/study.plan/lists.forms/supply.inventory.synoptic.txt)

Sample handling instructions: At the end of each 12-hour shift, the team coming off shift will prepare their nutrient/ chlorophyll-a samples for mailing to the U.S. Geological Survey Central Laboratory in Ocala, Fla., and biochemicaloxygen-demand and nutrient samples for delivery to the North Dakota Department of Health Laboratory in Bismarck, N. Dak. 






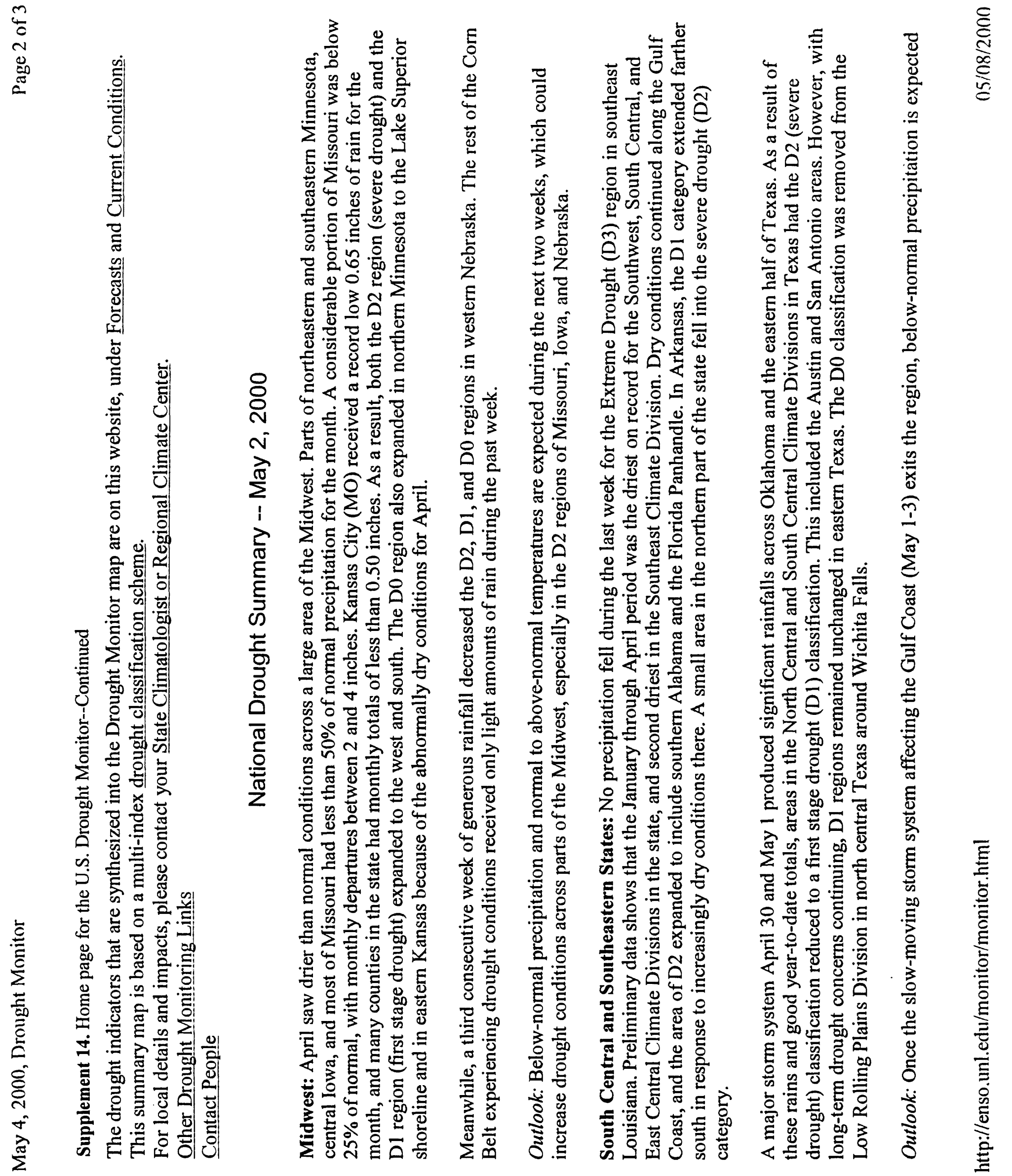
क

$\stackrel{0}{ \pm}$

焉

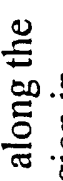

क्ष

政

政?

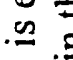

동

:

등

炡

年

舫

도다.

:



品足

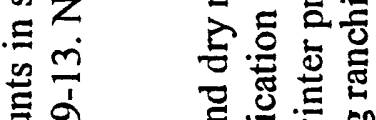

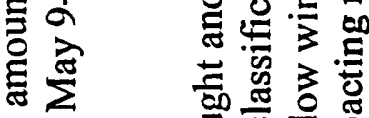

뜽

동

竞

巳

홍

范

항

$\sum^{\circ}$

(x)

站

产

क्ष

E

政。

棺

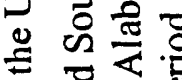

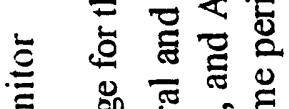

茄

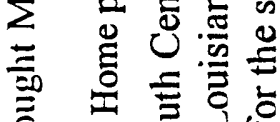

政

育

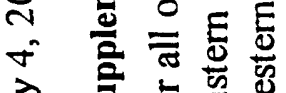

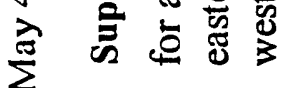

4

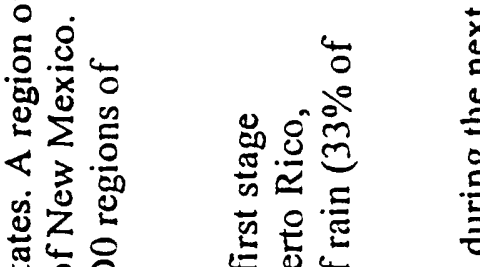

彮

응



Es

这

政

के

㠃.

है

突

(5)

政

政

O

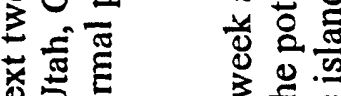

可

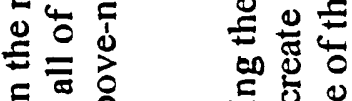

可

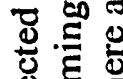

है

ธ

可是

월

可

흘을

歇元

声导宫

ठั

응

응

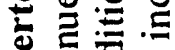

를

อ ठํ

产官号

"을

홍

릉르

:

중 ฐす气 흔흔 
Supplement 15. Mobilization captains

[File name: supp 15; file is a word file; --, unknown]

\begin{tabular}{llll}
\hline \multicolumn{1}{c}{ Name } & \multicolumn{1}{c}{ Agency } & Phone number & EMAIL address \\
\hline Ronald Jacobson & Minnesota Pollution Control Agency & (651) 296-7252 & ronald.jacobson@pca.state.mn.us \\
Mike Ell & North Daktoa Department of Health & (701) 328-5214 & mell@state.nd.us \\
Kelly Boespflug & U.S. Geological Survey, Grand Forks office & (701) $739-0216$ & klboespf@usgs.gov \\
Pete Bilstad & Fargo Wastewater-Treatment Plant & (701) $241-1454$ & -- \\
Bob Zimmerman & Moorhead Wastewater-Treatment Plant & (218) 299-5386 & -- \\
\hline
\end{tabular}




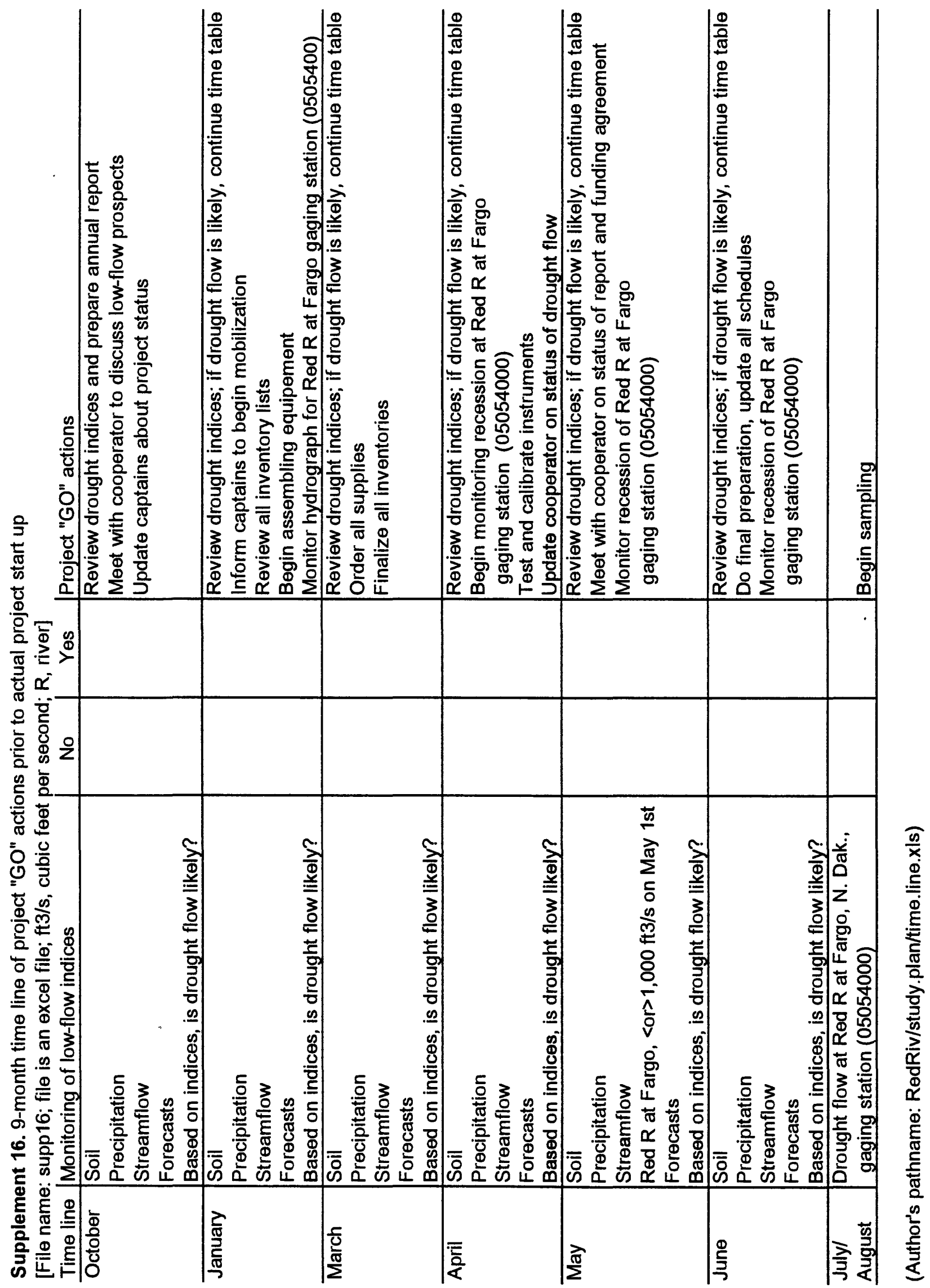

